\title{
Advances in the slow freezing cryopreservation of microencapsulated cells
}

Authors: Gurruchaga $\mathrm{H}^{\mathrm{a}, \mathrm{b}}$, Saenz del Burgo $\mathrm{L}^{\mathrm{a}, \mathrm{b}}$, Hernandez $\mathrm{RM}^{\mathrm{a}, \mathrm{b}}$, Orive $\mathrm{G}^{\mathrm{a}, \mathrm{b}}$, Selden $\mathrm{C}^{\mathrm{c}}$, Fuller $\mathrm{B}^{\mathrm{d}}$, Ciriza $\mathrm{J}^{\mathrm{a}, \mathrm{b}^{*}}$, Pedraz $\mathrm{JL}^{\mathrm{a}, \mathrm{b}^{*}}$

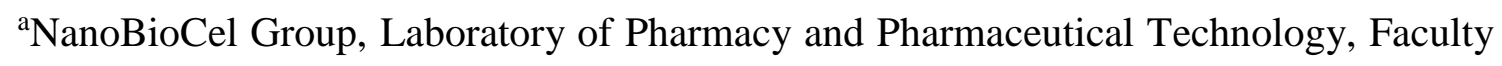
of Pharmacy, University of the Basque Country, UPV/EHU, Vitoria-Gasteiz, Spain

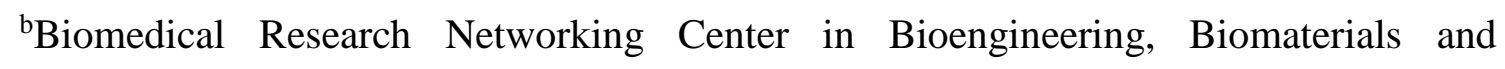
Nanomedicine, CIBER-BBN, Vitoria-Gasteiz, Spain

${ }^{c}$ UCL Institute for Liver and Digestive Health, Royal Free Hospital Campus, UCL Medical School, London, UK.

${ }^{\mathrm{d} U C L}$ Division of Surgery and Interventional Science, Royal Free Hospital Campus, UCL Medical School, London, UK.

\section{Authors affiliations:}

Haritz Gurruchaga

NanoBioCel Group, Laboratory of Pharmacy and Pharmaceutical Technology, Faculty of Pharmacy,

University of the Basque Country

Paseo de la Universidad 7

Vitoria-Gasteiz, 01006, Spain

Phone number, +34945014518

E-mail: haritz.gurruchaga@ehu.eus

Laura Saenz del Burgo, PhD

NanoBioCel Group, Laboratory of Pharmacy and Pharmaceutical Technology, Faculty of Pharmacy

University of the Basque Country UPV/EHU

Paseo de la Universidad 7

Vitoria-Gasteiz, 01006, Spain

Phone number, +34945014518 
E-mail: laura.saenzdelburgo@ehu.eus

Rosa María Hernández, $\mathrm{PhD}$

NanoBioCel Group, Laboratory of Pharmacy and Pharmaceutical Technology, Faculty of Pharmacy

University of the Basque Country UPV/EHU

Vitoria-Gasteiz, 01006, Spain.

Phone number: +34945013095

Fax number: +34945013040

E-mail address: rosa.hernandez@ehu.eus

Gorka Orive, $\mathrm{PhD}$

NanoBioCel Group, Laboratory of Pharmacy and Pharmaceutical Technology, Faculty of Pharmacy

University of the Basque Country UPV/EHU

Vitoria-Gasteiz, 01006, Spain.

Phone number: +34 663027696

Fax number: +34 945013040

E-mail: gorka.orive@ehu.eus

Clare Selden, $\mathrm{PhD}$

University College of London (UCL), Institute for Liver and Digestive Health,

Royal Free Hospital Campus

Rowland Hill street, Hampstead

London NW3 2PF, UK.

Phone number: +44 02074332854

E-mail: c.selden@ucl.ac.uk

Barry Fuller, $\mathrm{PhD}$

University College of London (UCL), Division of Surgery and Interventional Science Royal Free Hospital Campus 
Pond St, Hampstead

London NW3 2QG, UK.

Phone number: +44 020794050034190

E-mail: b.fuller@ucl.ac.uk

Jesús Ciriza, PhD (corresponding author)

NanoBioCel Group, Laboratory of Pharmacy and Pharmaceutical Technology, Faculty of Pharmacy

University of the Basque Country UPV/EHU

Paseo de la Universidad 7

Vitoria-Gasteiz, 01006, Spain

Phone number, +34945014518

E-mail: jeciriza@gmail.com

José Luis Pedraz, PhD. (corresponding author)

NanoBioCel Group, Laboratory of Pharmacy and Pharmaceutical Technology, Faculty of Pharmacy.

University of the Basque Country UPV/EHU

Paseo de la Universidad 7

Vitoria-Gasteiz, 01006, Spain.

Phone number: +34945013091 .

Fax number: +34945013040 .

E-mail address: joseluis.pedraz@ehu.eus 


\begin{abstract}
Over the past few decades, the use of cell microencapsulation technology has been promoted for a wide range of applications as sustained drug delivery systems or as cells containing biosystems for regenerative medicine. However, difficulty in their preservation and storage has limited their availability to healthcare centers. Because the preservation in cryogenic temperatures poses many biological and biophysical challenges and that the technology has not been well understood, the slow cooling cryopreservation, which is the most used technique worldwide, has not given full measure of its full potential application yet. This review will discuss the different steps that should be understood and taken into account to preserve microencapsulated cells by slow freezing in a successful and simple manner. Moreover, it will review the slow freezing preservation of alginate-based microencapsulated cells and discuss some recommendations that the research community may pursue to optimize the preservation of microencapsulated cells, enabling the therapy translate from bench to the clinic.
\end{abstract}

Keywords: cryoprotectant (CPA), dimethylsulfoxide (DMSO), slow freezing, drug delivery, cell microencapsulation, alginate 


\section{Introduction}

The increasing use of cell therapies for the treatment of diverse diseases has promoted the research of the areas that will enable the advance and spread of these therapies. In this way, a process that will allow correct storage, shipment and delivery of cell-based products has also gained attention. One of the possible methods for the delivery of cell-based products is refrigerated shipment or short-term preservation. However, this method will only permit storage for a few days and rules out the possibility of being a desirable method for long-term storage or delivey. Thus, the preservation at deep cryogenic temperatures (ranging from $-196^{\circ} \mathrm{C}$ to approximately $150^{\circ} \mathrm{C}$ ) where cells, tissues, cell-based products or organs are suspended in a tissue medium with one or more cryoprotectants (CPAs), a process named cryopreservation, is the only technology that enables "holding the biological clock" of cell-based products and facilitates the "on demand" access of patients to the treatments in a clinic far from the manufacturer [1,2]

Theoretically, if cryopreservation works successfully, it should provide a quality product that ensures the previous characteristics are kept. However, during the cryopreservation process several mechanisms lead to cell damage and compromise product quality and integrity. The size of the samples, as an example, represents an obstacle for the penetration of CPAs and can interfere with cooling and warming profiles [3]. The exposure of the embedded cells to the CPA depends on the cell location in the structure, which could lead to different cell viabilities throughout the cell-based construct. In this sense, there are different protocols for storing cell therapies, offering both advantages and drawbacks that should be taken into consideration to ensure the correct storage of the cell-products (Table 1). Currently, the most used procedures are either slow freezing or vitrification. Vitrification is a rapid freezing method at which a solution, using high amounts of CPAs (excess of $40 \% \mathrm{w} / \mathrm{v}$ ), is cooled below its glass transition temperature without ice crystal formation leading to an amorphous matrix that could also be defined as an extremely cold viscous liquid [4]. In this method, ice formation is avoided throughout the entire sample, but these high CPA concentrations are normally toxic to mammalian cells, oblying to minimize the exposure to CPAs complicating the handling process [5-7]. The controlled rate or slow freezing has been developed over the past 40 years, establishing protocols to preserve samples such as embryos, cells, blood products or stem cells among others [8-10]. 
In contrast to vitrification, samples are cooled in a controlled way (for mammalian cells $-1{ }^{\circ} \mathrm{C} /$ minute) using lower concentrations of CPAs, and thus, producing ice crystals. The intracellular ice formation (IIF) is avoided with the use of slow cooling rates and the dehydration of cells, and even if ice crystals are nucleated in the samples, cell viability and function are preserved in different cells, tissues, and cell-based products [11,12]. This method is also used for larger samples and technically is a simpler procedure than vitrification [4]. Moreover, slow freezing does not need advanced equipment, and in the case of alginate cell-based products, almost all samples are preserved using this protocol [12-15]. This review will discuss the slow freezing method for the preservation of cell-based products. The steps for a successful slow freezing will be summarized and the preservation of the alginate-based cell products will be discussed.

Table 1: Advantages and drawbacks of the different cryopreservation methods

\begin{tabular}{|c|c|c|}
\hline & Advantages & Drawbacks \\
\hline \multirow{3}{*}{ Slow freezing } & Low concentrations of CPA & \\
\hline & Simple handling and equipment & Ice creation through sample \\
\hline & Possibility to storage large volumes & Possible structure/tissue damage \\
\hline \multirow{5}{*}{ Vitrification } & \multirow{3}{*}{ Ice creation is prevented } & High amounts of CPAs \\
\hline & & \\
\hline & & CPAs related toxicity \\
\hline & \multirow{2}{*}{ Preservation of tissues structures } & \\
\hline & & $\begin{array}{c}\text { Complex addition and removal } \\
\text { of CPAs }\end{array}$ \\
\hline
\end{tabular}

\section{Cell injury in slow freezing}

Undestanding of the mechanisms that could damage cell viability and function is essential for the cryopreservation of cell-based systems. During the slow freezing process, the ice crystal formation in the whole sample cannot be avoided. Therefore, a successful protocol with an optimal cooling rate that prevents major injury mechanisms (e.g. IIF, solute toxicity and osmotic damage) should be employed.

Cryoprotectant (CPA) is a term coined to describe "any additive which can be provided to cells before freezing and yields a higher post-thaw survival than can be obtained in its absence" [16,17]. CPAs reduce the water content in cells/tissues and increase the total concentration of all solutes. They are added before cryopreservation to the freezing solution to prevent the IIF in the process, which is associated with lethal 
cell injury in the majority of cases [18]. However, the CPA concentration for obtaining a beneficial effect, is far higher than other solutes in normal cell media solutions, and compromise its use by its toxicity. In the cryopreservation process, when CPAs are added to samples, cells will initially shrink as water leaves the cells by osmosis in response to the increased solute concentration extracellularly. If permeating CPAs are employed, after the initial shrink cells will swell while CPA crosses the cell membrane. This later exchange of CPAs is due to the cells increased permeability to water rather than solutes [19]. By contrast, if only non-permeating CPAs are used, this swelling will not be occur and cells will remain dehydrated. Even though the CPAs are necessary in cryopreservation to prevent IIF, the addition and removal of CPAs could exert the above-mentioned osmotic stress on cells, which may result in excessive cell injury or death [20]. Thus, the addition of CPAs should be controlled precisely to ensure cell function and viability after the storage.

The kinetics of cooling rates also influence the outcome of the cryopreservation. From the empirical observation of the slow cooling profiles, and their good results, Mazur and colleges proposed a hypothesis to explain the biophysical processes that occur during cryopreservation, the called Mazur's two-factor hypothesis (Figure 1). In the slow freezing preservation, cells are required to be optimally dehydrated to avoid IIF. At an optimal cooling rate, cells would be dehydrated with their sensitive molecular and ultrastructural components protected by the added CPA. However, if a too fast cooling rate is used, cells will not have time to dehydrate, and intracellular ice could form from the remaining residual intracellular water. By contrast, with a too slow cooling rate, cells will suffer an irreversible injurious dehydration from the long exposure to hypertonic solutions. This could disrupt the biochemical and physical conditions required for cell survival, and mitochondria and endoplasmatic reticulum could structurally be compromised. In this sense, the "inverted U" survival effect showed graphically by Mazur is displayed in one of the best cold biology compilations (Figure 1) [21]. In that compilation, different cell types are pulled together todemonstrate that even when the difference between the optimal cooling rates of diverse cell types is huge, this "inverted U" survival interval could be observed in all. However, this is an oversimplification of the complex biophysical processes occurring during cryopreservation, and many still remain unclear [22]. Nevertheless, the twofactor hypothesis has been observed in many other results after its proposal, and its 
utility to study and optimize the slow freezing protocols of different cell-based therapies is undoubted.

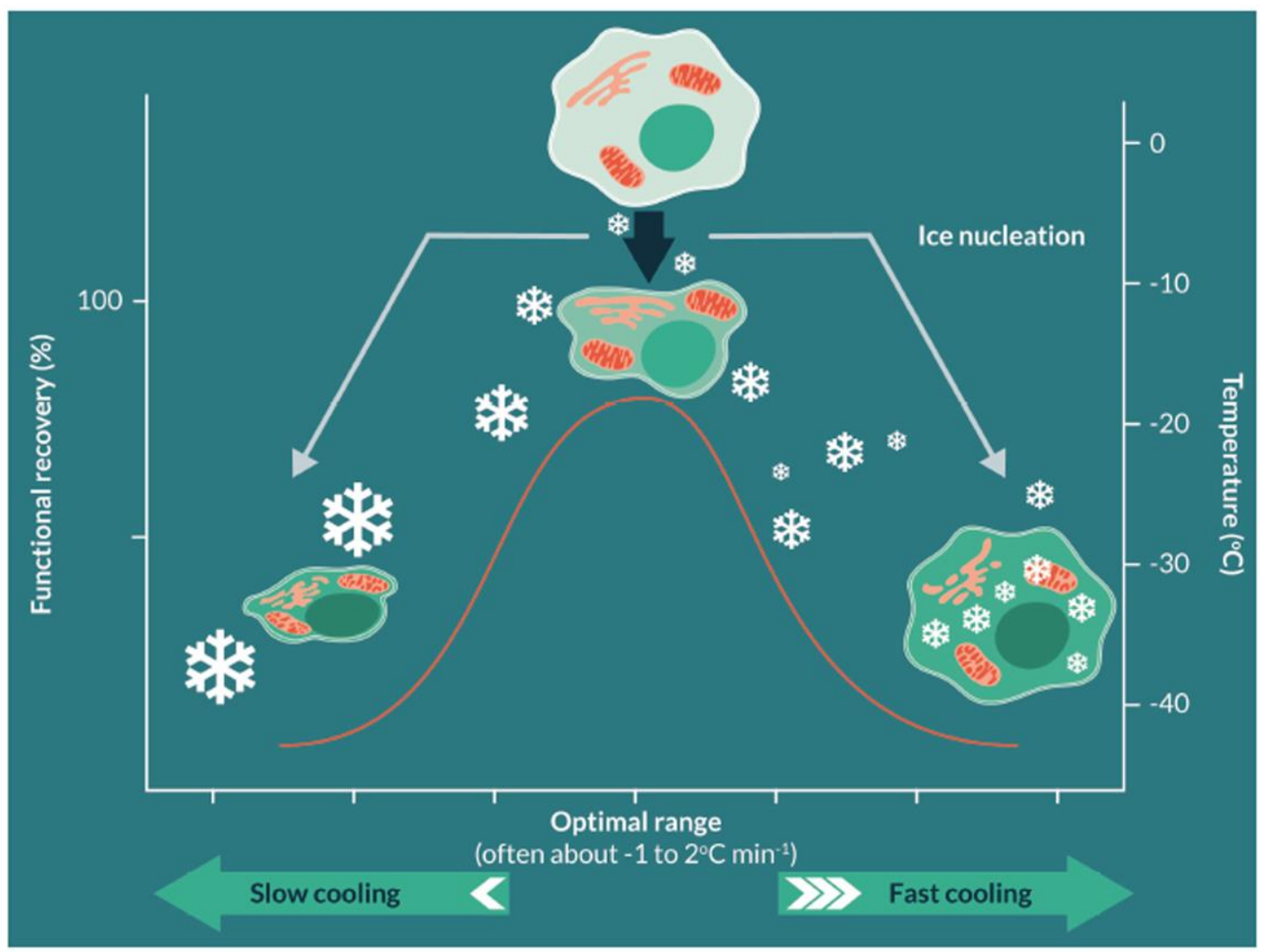

Figure 1: Schematic of Mazur's 2-factor hypothesis. A cell with CPA protection subjected to cooling at different rates. Maximum functional recovery is achieved with an optimal cooling rate providing reversible dehydration occurring over the high subzero temperature range. If cooling is too slow, irreversible injurious dehydration can take place, for example the mitochondria and endoplasmic reticulum are structurally compromised. If cooling is too fast, cells do not have time to optimally dehydrate, and residual intracellular water can form ice, which is again injurious and can compromise structure of organelles. For many nucleated mammalian cells, 'optimal' cooling equates to rates of around $-1{ }^{\circ} \mathrm{C} \mathrm{min}^{-1}$. Copyright of BioInsights Publishing Ltd. Cell Gene Therapy Insights 2017; 3(5), 359-378. DOI: 10.18609/cgti.2017.038.

\section{Steps in a slow freezing protocol}

The cell-based products are subjected to different proccesses during the slow freezing cryopreservation, and each of these have to be properly performed to cryopreserve cells successfully (Figure 2). Cell-based systems have to be prepared to undergo freezing, and an appropriate CPA solution has to be chosen avoiding the mechanism that could impair the cell-based products function and integrity. Moreover, the samples should be preserved at the adequate temperatures, and although the thawing has not be given as much importance as the cooling, it deserves the same attention. The 
steps that should taken in consideration to achieve a successful slow freezing cryopreservation will be next summarized and discussed.

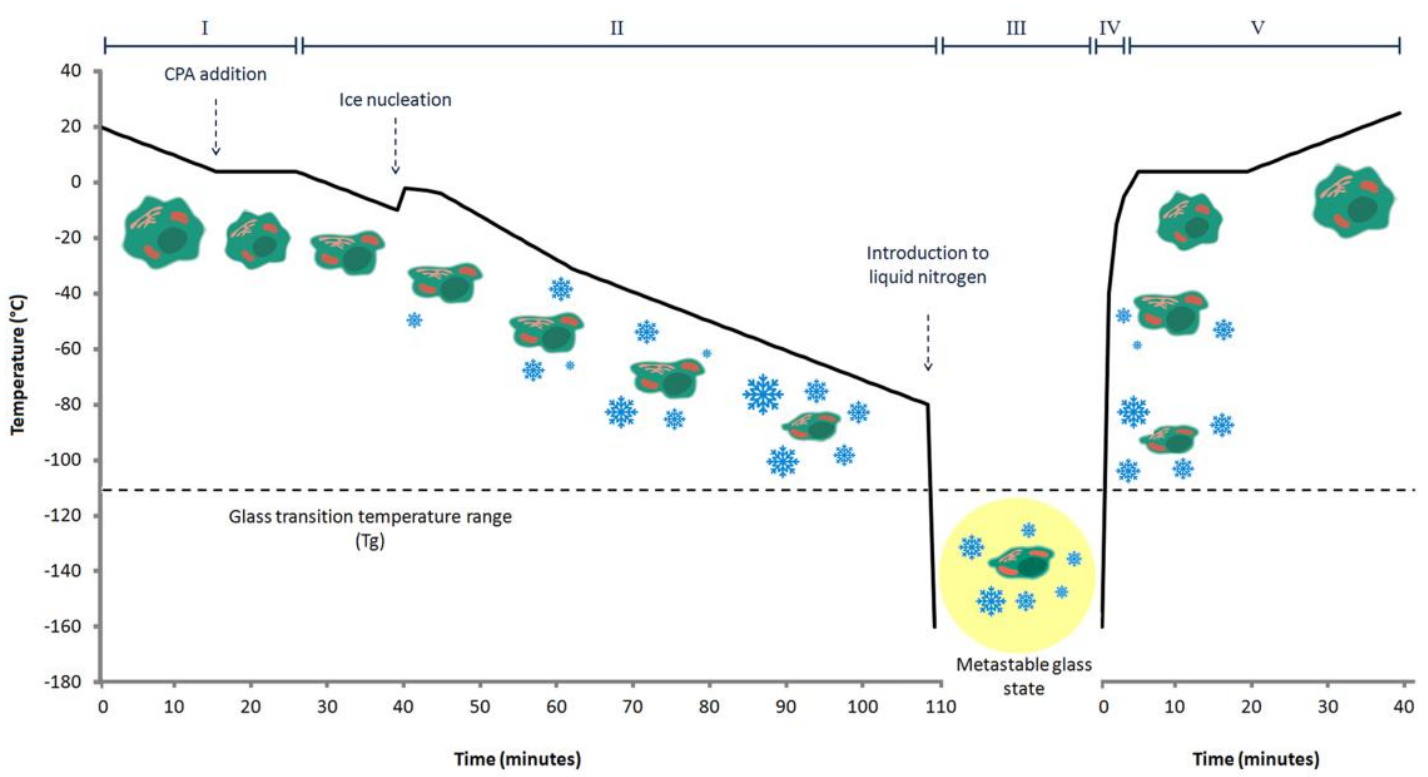

\begin{tabular}{|c|c|c|c|c|}
\hline $\begin{array}{c}\text { I } \\
\text { Samples preparation for freezing }\end{array}$ & $\begin{array}{c}\text { II } \\
\text { Cooling }\end{array}$ & $\begin{array}{c}\text { III } \\
\text { Storage }\end{array}$ & $\begin{array}{c}\text { IV } \\
\text { Thawing }\end{array}$ & $\begin{array}{c}\mathrm{V} \\
\text { CPA removal }\end{array}$ \\
\hline $\begin{array}{l}\text {-Chill samples to } 0-4^{\circ} \mathrm{C} \text { to avoid CPA } \\
\text { toxicity } \\
\text {-Consider adding the cooled CPA } \\
\text { solution }\left(4^{\circ} \mathrm{C}\right) \text { gradually to prevent } \\
\text { toxicity and osmotic changes } \\
\text {-Let enough time to equilibrate } \\
\text { samples with the CPA solution }\end{array}$ & $\begin{array}{l}\text { - Consider measuring sample } \\
\text { temperature } \\
\text {-Controlled rate freezers enables } \\
\text { further control of cooling profile } \\
\text {-Induced ice nucleation may } \\
\text { improve cell outcome } \\
\text { - Slow cooling below the }-60 \text { to } \\
100^{\circ} \mathrm{C} \text { has no benefits }\end{array}$ & $\begin{array}{l}\text {-Below the glass transition } \\
\text { temperature (Tg) samples } \\
\text { preservation period is extended } \\
\text {-Storage within vapor phase or liquid } \\
\text { nitrogen is the most common method } \\
\text {-Consider measuring sample } \\
\text { temperature to control and avoid } \\
\text { temperature fluctuations during the } \\
\text { storage }\end{array}$ & $\begin{array}{l}\text {-Fast thawing is the most used } \\
\text { method to avoid regrowth of } \\
\text { ice nuclei } \\
\text {-For large volumes samples, } \\
\text { slow thawing could be } \\
\text { interesting to prevent different } \\
\text { post-thaw cell outcome } \\
\text { through sample }\end{array}$ & $\begin{array}{l}\text { - Remove the CPA solution } \\
\text { gradually to avoid osmotic } \\
\text { changes } \\
\text {-Do not warm samples until } \\
\text { CPA is removed to avoid } \\
\text { CPA related cytotoxicity }\end{array}$ \\
\hline
\end{tabular}

Figure 2: Schematic process of slow cooling cryopreservation. Cells are usually chilled to avoid the cytotoxic effect of CPAs, and at $\sim 4^{\circ} \mathrm{C}$ the cooled CPA solution is added, enabling CPAs to permeate the cells during a holding time. Then samples are cooled slowly, and usually around $-7^{\circ} \mathrm{C}$ ice nucleation occurs. That could be induced by active nucleation or modulated by adding an ice nucleating agent to the CPA solution. Samples continue cooling until $-80^{\circ} \mathrm{C}$, where samples are cooled below the glass transition temperature by nitrogen liquid immersion, approx. $-160^{\circ} \mathrm{C}$, and held in the cryogenic state. The cryopreserved samples will form a solidified mixed matrix of ice, CPAs, solute and a biomass, composed of extremely dehydrated cells that contain no ice. When is required, samples could be thawed quickly, and after CPA removal at $\sim 4^{\circ} \mathrm{C}$ the sample would be ready to use.

\subsection{Choice of CPA solution}

The CPA solution is one of the variables that is being optimized to improve the outcome of the cell-based products recovered from cryopreservation. Since the required CPA concentration to prevent IIF are not the physiological ones present in the cell media solutions, a long exposure time could lead to non reversible cell damage $[17,23]$. Thus, researchers always tend to reduce as much as possible the amount of CPAs in the 
solution, being a research line the combination of different CPAs to decrease their related toxicity [24]. It was established a distinction between CPAs, depending if were able or not to permeate the cell membrane (Table 2). Permeating CPAs such as glycerol, are molecules of low molecular weight that can go through the cell membrane by osmosis, replace the water inside the cells and hold the non-freezable water within the cells [17]. The most common is dimethylsulfoxide (DMSO), it is included in the range of 5 to $12 \%(\mathrm{v} / \mathrm{v})$ in most of the CPA solutions for every cell type with excellent results $[8,11,12,14,15]$. For example Hemacord®, an allogeneic cord blood hematopoietic progenitor cell therapy product which is approved by the FDA, is cryopreserved with DMSO obtaining great results in clinics. However, DMSO employment was related to adverse effects after the transplantation of cryopreserved cell therapy products, and many researchers started to reduce the amount employed in their protocols, or even remove it $[25,26]$. After reviewing some of the clinical trials procedure that showed DMSO toxicity, it was found that DMSO was not entirely removed or that some procedures were not appropriately performed, and some experts claimed that the related adverse effect of DMSO could have been avoided [27]. In this respect, a report of an expert meeting discusses the path that research may take to make progress in successful preservation of cell therapy products, and recommends that an actual review addressing the reality of DMSO toxicity would be extremely valuable to go forward in cell-based products employment [28]. Nevertheless, other research groups are also adding non-permeating CPAs to speed up the dehydration process of the cells in supra-zero temperatures and reduce their toxicity. In this sense, sucrose and trehalose are the most used non-permeating CPAs at concentration ranges between $0.1-0.3 \mathrm{M}$. They have been added to many protocols obtaining better results than with DMSO alone, and allowed in some studies the decrease of DMSO percentage in the CPA solution [24]. In the cryopreservation of human umbilical cord as source of Wharton's jelly mesenchymal stem cells, the CPA solution that combine DMSO 10\% and Sucrose 0,2M displayed better results than only DMSO $10 \%$ in terms of MSCs isolation and expansion from the umbilical cord after thawing [29]. It should be borne in mind, that intracellular ice protection is required in the cryopreservation of nearly all nucleated mammalian cells, and that non-permeating CPA could provide some benefits in the extracellular environment, but not the primary ice protection inside the cells. Thus nonpermeating CPAs are usually used in addition to permeant CPAs. However, if the nonpermeating CPAs, such as sucrose and trehalose were able to permeate inside the cell 
before cryopreservation, the use of permeating CPAs such as DMSO could be avoided entirely [30]. Zhang et al. cryopreserved fibroblasts with only trehalose in the CPA solution, inducing trehalose uptake during freezing. Although the cell recovery was not as high as with DMSO 10\%, they demonstrated that fibroblast can be cryopreserved without the use of permeant CPAs [31,32].

Table 2: Sumary of cryoprotectants selected for cell preservation. Identified by widespread $^{* * *}$, moderate** or infrequent* choice of agent.

Common Cryoprotectants (CPA)

Cell permeating agents

Non-permeating agents

\begin{tabular}{lll}
\cline { 2 - 3 } & \multicolumn{1}{c}{ Sugars } & \multicolumn{1}{c}{ Polymers } \\
\hline Dimethyl sulphoxide*** & Sucrose**** & Polyethylene glicol (PEG)*** \\
Ethylene glycol*** & Trehalose*** & Polyvinyl pyrrolidone (PVP)*** \\
Propylene glycol*** & Raffinose** & Hydroxy ethyl starch*** \\
Glycerol** & Mannitol** & Ficoll** \\
Methanol* & Glucose* & Serum proteins (mixture) \\
Ethanol* & Galactose* & Milk proteins (mixture) \\
\hline
\end{tabular}

Particular CPA mixtures are often selected for specific cell preservation strategies. This list is not exhaustive and a wider discussion can be found on $[17,23]$. Oligosaccharides tend to act as non-permeating osmotically acting CPAs, whereas monosaccharides may permeate cells to a degree depending on cell type. Copyright of BioInsights Publishing Ltd. Cell Gene Therapy Insights 2017; 3(5), 359-378. DOI: 10.18609/cgti.2017.038

Other additives, which facilitate cryopreservation but have no clear primary role as permeant and non-permeant CPA and are not defined as CPAs, are usually added to the CPA solution to increase cell recovery after the cryopreservation and thawing processes. The use of antioxidants in the CPA solution has been applied for several decades in the preservation of sperm, follicles and plants [33,34]. From the abovementioned cell injury mechanisms in the cryopreservation, reactive oxygen species are created. Reactive oxygen species have been implicated in different damages mechanisms, such as lipid peroxidation of membranes, damage in the DNA, and loss of motility and fertility in frozen and thawed sperm $[33,34]$. In this sense, the properties of antioxidants could reduce the impact of reactive oxygen species and cold shock damage improving preservation of cell function after thawing. Recently, the antioxidants used 
have been translated to the cryopreservation of other cell-based therapies, such as the hematopoietic and mesenchymal stem cells [35-37]. Although the most used antioxidants for these cell types are catalase and ascorbic acid, others such glutathione or n-acetylcysteine can also be used. As always, the used concentration is crucial and must be optimized for obtaining a positive outcome after the samples thawing [38]. Thus, these results suggest that antioxidant inclusion in CPA solution could improve the recovery for a wide range of cells, and raise the question if lots of established protocols should be modified by the inclusion of antioxidants.

In the same way, antifreeze proteins have also been included to reduce the IIF. Mainly as antioxidants, their use has been focused on the preservation of reproductive cells or embryos [39]. These molecules are ice-binding proteins that prevent water from freezing by adsorbing to the ice surface and stopping the growth of diminutive ice crystals to large crystals in a non-colligative manner. They have been associated with other function such as thermal hysteresis or interaction with membranes and/or membrane proteins, and due to these characteristics they were employed in the freezing protocols of different cell lines [40-42]. The cryopreservation efficiencies have usually been enhanced regardless of cell type and freezing method, with a handful of exceptions. In spite of these effects, it is agreed that the employment of antifreeze proteins in cell storage needs a further tuning to clarify the molecules effects on cryopreservation, as outcome depends on the antifreeze protein, preserved cell, CPA solution, and storage temperature. Also, fetal bovine serum (FBS) has been described as another additive included in several cryopreservation protocols with beneficial effect. FBS stabilizes cell membranes, decreases the extracellular ice formation, minimizes cell dehydration and prevents excessive concentration of solutes during the freezing/thawing process [43]. However, clinicians try to avoid FBS in the cryopreservation of cells such as mesenchymal stem cells (MSCs) to reduce the risk of xeno-derived infection [44,45], for example, by the use of human serum. Moreover, the variation between the used human serum batches can be significant; some reports showed beneficial effects when it was included in the CPA solution [46], and others not [47].

Lastly, ice nucleating agent inclusion in the CPA solution enhanced the freezing survival of different cell types [16]. Ice nucleating agents such as silver iodide, metallic particles or other organic compounds produced by multiple organism, are molecules that due to their structural and surface properties, facilitate the orientation of water molecules to an ice-like structure, creating active germ crystals. During 
cryopreservation, aqueous solutions may become super-cooled, taking place the phase transition from liquid to solid stochastically. The uncontrol of this phenomenon leads to high sample to sample variations in terms of cell viability after thawing [48]. Thus, active control of ice nucleation can lead to cryoinjury reduction during freezing $[12,13,49]$. However, the mechanism behind the increased cell survival is not clear yet. Some studies indicate that the membrane phase changes occurring during controlled nucleation, may reduce the incidence of IIF [50]. Moreover, if ice nucleation is closer to the melting point of the solution, the dehydration of cells would be more pronounced due to extracellular ice formation. This longer period of cell dehydration is the phenomenon that has been related to the increase of cell viability after cryopreservation [51]. Lauterboeck et al. ratified this mechanism, reporting that the active control of nucleation temperature above the spontaneous nucleation temperature leads to a higher dehydration of mesenchymal stem cells, reducing the IIF [52]. The highest ice nucleation temperature did not achieve the best results. The $-10^{\circ} \mathrm{C}$ degrees was the best nucleation temperature for mesenchymal stem cells, which maintained a higher percentage of membrane integrity and cell recultivation when samples were frozen with 5\% DMSO (Figure 3A). Also, Massie et el. demonstrated how the ice nucleation affects the post-warming viability of microencapsulated liver spheroids [12] (Figure 3B). Higher ice-nucleating temperatures, using cholesterol as a nucleating agent, resulted in doubling cell viability of the microencapsulated liver spheroids after thawing. Moreover, the ultrastructural effects of controlled ice nucleation compared to spontaneous ice nucleation were also displayed in microencapsulated liver spheroids by cryoscanning electron microscopy [12] (Figure 3C). During controlled ice nucleation slower ice formation was created enabling cells to dehydrate appropriately (Figure 3C1,3). By contrast, following spontaneous ice nucleation, intercellular ice was formed provoking cell injury (Figure 3C-2,4). Between the nucleation agents, there are some chemicals such as cholesterol or Icestart ${ }^{\mathrm{TM}}$, but also nucleation could be induced by a controlled metal straw placed inside the samples. These nucleating agents seed the production of an ice embryo and enable the propagation of gradual ice formation through the remainder of the sample, and as above mentioned, reduces the sample to sample variations. Thus, one should consider, as with antioxidants, the inclusion of an ice nucleator in CPA solutions to improve the cell survival after freezing, especially in large samples in which ice nucleation is more heterogeneous. 
A

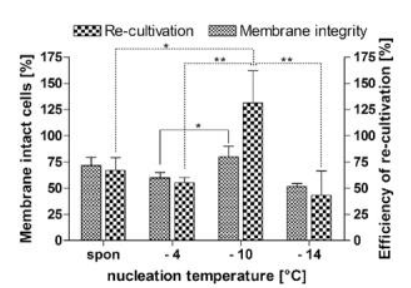

C
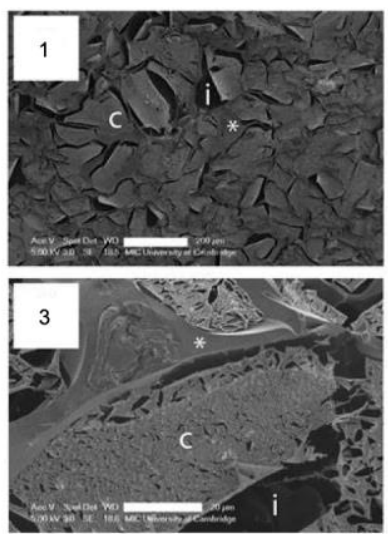

B
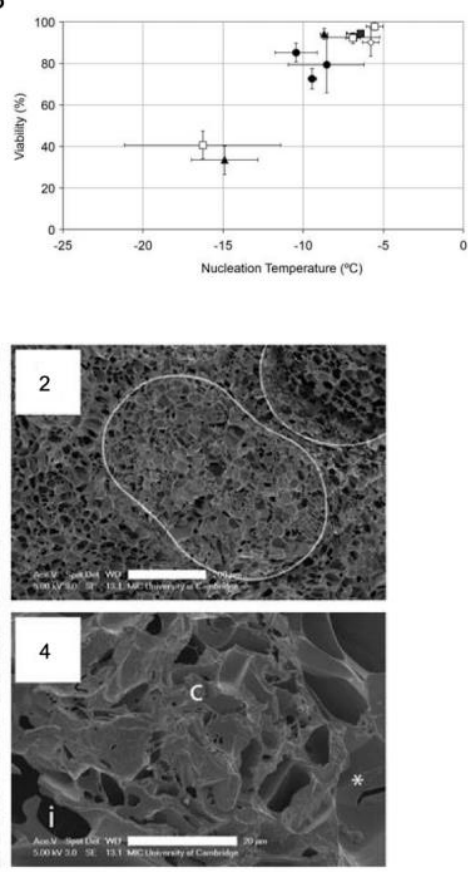

Figure 3: Ice nucleation affects on the recovery of microencapsulated cells. A) Evaluation of membrane integrity and efficiency of re-cultivation after cryomicroscopy on primate MSCs. B) Microencapsulated cell spheroids viability when cooled under different cooling protocols showing that regardless the used protocol, higher ice nucleation results in higher viabilities. C) Cryoscanning electron microscopy of fractured cryovials after cooling at a linear rate of $-1{ }^{\circ} \mathrm{C} / \mathrm{min}$. Ultrastructure resulting from controlled ice nucleation $(\mathrm{A}, \mathrm{C})$ is compared to spontaneous ice nucleation $(2,4)$. In figure (B) sectioned alginate beads that are $~ 500$ $\mu \mathrm{m}$ in diameter are outlined. In $(1,3,4)$, cell clusters (c), ice voids (i), and smooth freeze concentrated alginate and cryoprotectant (CPA) $(*)$ have been labeled. Scale bars on $(1,2) 200 \mathrm{~mm}$, and on $(3,4) 20 \mathrm{~mm}$. Notes: Spon: spontaneous *p < 0.05; $* * \mathrm{p}<0.01$. $(\mathrm{n}=3)$. A) Reprinted from Active control of the nucleation temperature enhances freezing survival of multipotent mesenchymal stromal cells, 71(3), Lauterboeck L, Hofmann N, Mueller T, Glasmacher B, Cryobiology , 384-90, Copyright (2018), with permission from Elsevier. (B and C as originally published in [12])

\subsection{Sample preparation for freezing}

Before samples are loaded into freezing machines and suffer cooling, different processes are carried out, such as sample chilling and CPA solution addition. Although these processes seem simple, some variables have to be taken into account to perform them appropriately. Many CPAs, such as DMSO, are more toxic at temperatures higher than $4^{\circ} \mathrm{C}$ [17]. Therefore, cell-based products should be chilled to avoid CPA induced 
citoxicity. As mentioned before, the CPA concentration is not the one usually used in normal cell media, since it can be toxic to cells. So, chilling samples leads to a reduction in cell metabolic activity and consequently, lower CPAs toxicity [53]. However, this effect also reduces the permeability of CPAs to cells. Longer CPA exposure time are necessary if CPA addition is performed at lower temperatures, which could also increase toxicity [53]. In this case, the beneficial effect of lowering the metabolic activity is prioritized in the slow freezing cryopreservation [54]. Furthermore, in order for samples to follow the applied cooling rate and reduce variability, it is recognized that samples should be pre-chilled to around $0-4^{\circ} \mathrm{C}$ before freezing. The introduction of samples to the freezer or the controlled rate freezers (CRF) without chilling, could lead to differences between the real and the theoretical cooling rates of the sample. Therefore, even after applying an optimized cooling rate that reduces as much as possible IIF, samples may not recover their function after thawing. Also, there are reports that adding the chilling step before cooling improves cell recovery [55]. Furthermore, when large volume samples, such as tissues or red blood cell cryobags are frozen, this is an essential point to bear in mind [56]. Thick or large volume samples are not homogeneously cooled, and sample introduction into the cooling machine without cooling could lead to enhances sample to sample function variability after freezing and thawing.

The osmotic changes that occur when the CPA solution is added or removed, could also be detrimental to the diverse cell types. Some cells are more susceptible to osmotic changes than others, and the cooled CPA solution addition is performed gradually to decrease CPA toxicity. Moreover, it should be taken into consideration that CPAs should permeate all cells, exerting their protective effect in the entire sample. To this end, before cooling, the CPA solution should be in contact with the sample for long enough for the CPAs to permeate through all cells [57]. As with chilling, larger samples will need longer periods of exposure to CPAs, as demonstrated with the cryopreservation of intact articular cartilage [58]. Indeed, optimization of the CPA addition protocol for the cell product is required. As a take-home message, samples should be entirely chilled and permeated to CPAs before freezing, in order to prepare them appropriately for the next step in the slow freezing cryopreservation.

\subsection{Controlled rate cooling protocol}


The applied cooling rate should be optimized for each sample according to Mazur's two-factor hypothesis. The cooling rate affects the rate of formation and size of both intracellular and extracellular ice crystals, and also impacts solution effects that occur during the freezing process [59]. In this sense, the $-1{ }^{\circ} \mathrm{C}$ per minute cooling rate is often used as an optimized rate to freeze various mammalian cell types (e.g. with Mr. Frosty $^{\mathrm{TM}}$, CoolCell ${ }^{\circledR}$ or homemade freezing system passive devices) that showed repeatedly good results $[14,60]$. These passive cooling devices may be suitable for small volumes or sample numbers, but lack suitability for use in the cryopreservation of larger samples. By contrast, controlled cooling can be achieved by CRF based on various principles such as nitrogen vapor (e.g., Cryomed ${ }^{\mathrm{TM}}$ or Planer PLC) or electrical Stirling Engine Systems (e.g., Asymptote PLC) [12,13,55,61-63]. These technologies allow the application of different cooling rates within the same cooling protocol, providing a tool to achieve optimal cooling rates for cell survival during cryopreservation. Although the applied cooling rate is important, the control of the real cooling rate within samples is crucial. The placement of thermocouples in samples during cooling protocols enable the measurement of difference in cooling rates between different compartments of devices, samples, or even between layers of the same sample $[63,64]$. With these tools, the cooling rate can be corrected by changing the cooling programme if it is required. Small samples, such as cryovials, will closely match the cooling rate programmed by the machine. However, large volumes of samples, often used at clinical scale, will be more difficult to cool at the programmed cooling rate. Kilbride et al. demonstrated that the way that samples are cooled influences ice solidification within the sample [63]. Two different heat transfer modules designed for an electrical Stirling cooling machine were used to cryopreserve microencapsulated liver spheroids in cryovials. In this study, the way the ice solidified through the cryovial was studied with its effect on microencapsulated liver spheroids. When cryovials were cooled from a single surface of the cryovials, progressive ice solidification occurred in samples. By contrast, when the entire module applied the cooling to all surface of the cryovial, a dendritic network solidification was predominant. The cooling profiles were recorded, and showed that the vials that were entirely cooled (Figure 4A) matched much better the applied cooling profile those cooled just from the bottom (Figure 4B). Regarding viability and cell function, there were non-significant differences between the studied groups. By contrast, when samples larger than a few milliliters were cryopreserved, it has to consider that homogeneous cooling is a great challenge due to heat and mass transfer is 
slowed. This effect was demonstrated in the same study, when $2 \mathrm{~L}$ of $10 \%$ aqueous glycerol solution (having the same thermal properties of microencapsulated liver spheroid) was cryopreserved and the cooling profile of the different layers was measured. The diversity in cooling profiles in different layers of the biomass was demonstrated, confirming the difficulty in obtaining homogeneous cooling in large volumes (Figure 4C). Regarding cells, these cooling heterogeneity through the biomass will also be reflected in differences in cell dehydration, extracellular solute concentration, and ice crystal formation, that will affect enormously in cell function after cryopreservation.

Lastly, it has been established empiricaly that the slow cooling below $-60^{\circ} \mathrm{C}$ to $100^{\circ} \mathrm{C}$ has no benefits in the preservation of different systems [65]. Thus, after the cooling protocol reaches these temperatures, samples are further cooled (at faster cooling rates) and solidified into a glassy state to extend cell-based product storage life.
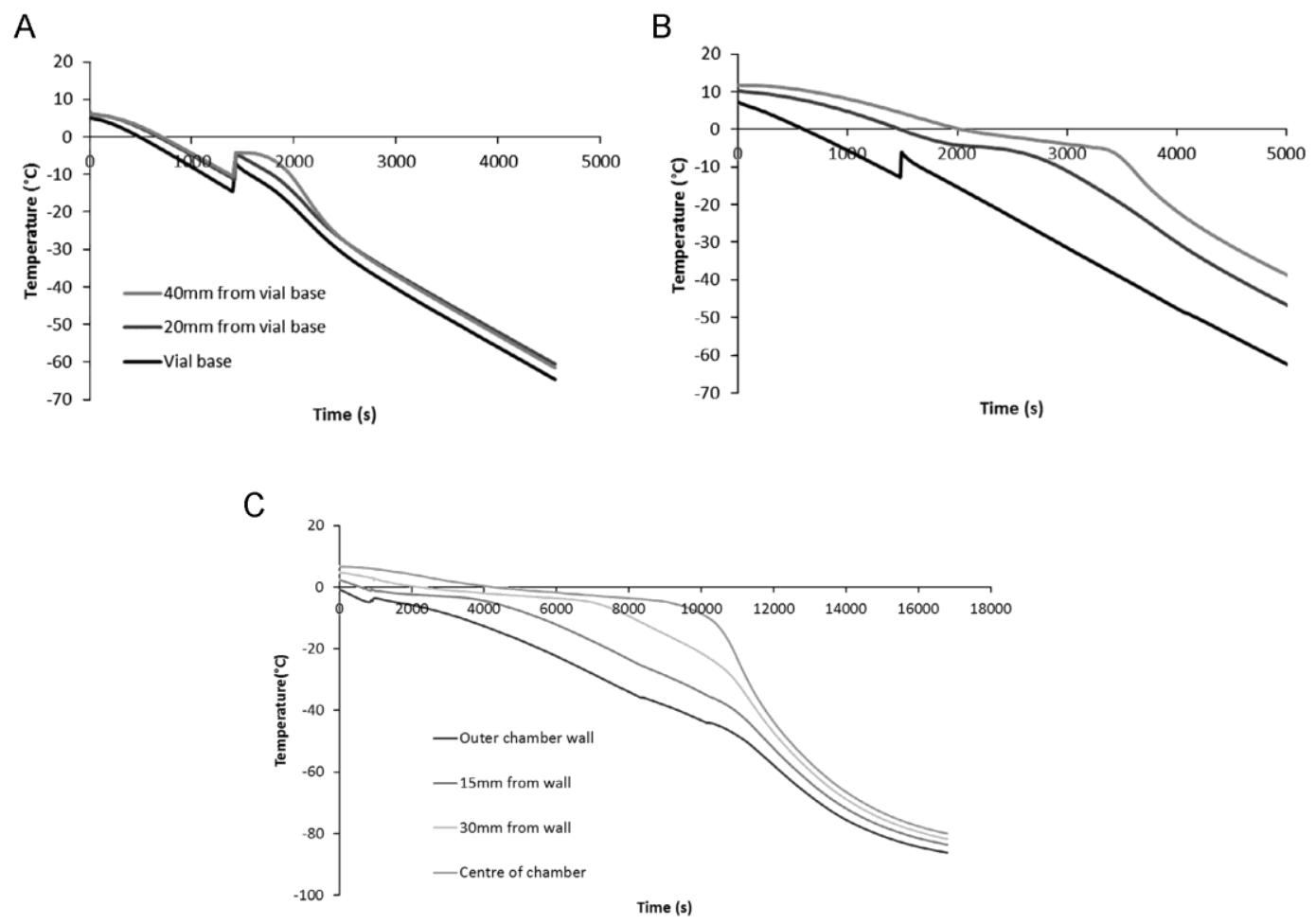

Figure 4: Differences in cooling profiles of cryovials and a $2 \mathbf{L}$ chamber. Temperature profiles in both aluminum (A) and acetal (B) heat transfer modules measured on the EF600-103 Stirling cryocooler-based controlled rate freezer. C) Measured temperature profiles inside the bioartificial liver chamber during cooling of a thermal mimic with $10 \%$ glycerol solution. (Figure as originally published in [63]) 


\subsection{Storage}

Depending on the desired storage time for the sample, different systems or methods can be used for the preservation of cell-based products. Samples preserved at 120 to $-130^{\circ} \mathrm{C}$ are so viscous due to highly concentrated CPA in the remaining solution, that enables samples phase change into a glassy state [66]. If the slow cooling protocol is successfully applied, below those temperatures, samples will form a solidified mixed matrix of ice, CPAs, solute and a biomass, composed of extremely dehydrated cells that contain no ice [12]. The temperature in which this phase transition occurs, called the glass transition temperature ( $\mathrm{Tg}$ ), depends on the solute concentration in samples. In this glassy state, the probability of chemical reactions or molecular diffusion occurring is highly unlikely due to insufficient thermal energy. The background ionizing radiation has been suggested as the only process that could exert harmful effects on samples, and more than a century would be necessary to accumulate lethal injury. Thus, this glassy state is desired for almost all storage systems to extend sample preservation periods.

The storage in vapor or liquid nitrogen $\left(-160^{\circ} \mathrm{C}\right.$ to $\left.-196^{\circ} \mathrm{C}\right)$ of cell-based products is the most often used method to preserve slowly cooled samples $[8,13,14,29,35,64]$. The temperatures achieved are far below of the Tg temperatures assuring safe long-term preservation of cell-based products. In this way, the successful preservation for 11 years of umbilical cord blood was achieved, with no impact on clinical outcomes, when transplants were stored in the vapor phase of liquid nitrogen [67]. However, the fluctuations in the liquid nitrogen levels (e.g., due to delays on filling of the tanks), or racks/ tray removal (e.g., to access specific products) could lead to significant temperature shifting that could be detrimental for cell recovery [68]. For example, a few minutes rack removal from the liquid nitrogen tanks to access a sample could upshift the temperature from -150 to $-100^{\circ} \mathrm{C}$ of all samples in the rack, leading them above the Tg temperature. Moreover, is demonstrated that samples preserved in liquid nitrogen can be contaminated, and thus, the storage in vapor phase nitrogen has been favored [69]. It also has to be mentioned, that temperature stability is not as uniform as in liquid nitrogen, and could compromise cell-based product long-term stability. By contrast, commonly used aluminum racks could stabilize the temperature, and other mechanisms such as the implantation of a copper heat shunt could also reduce the above-mentioned temperature fluctuations of samples in vapor phase [70]. The accurate control of sample temperatures within the storage period should be assessed to ensure their reproducibility. In this respect, the use of modern monitored storage 
containers which can be auto-filled may counter some of liquid and vapor nitrogen tanks drawbacks.

Storage at $-80^{\circ} \mathrm{C}$ using electrical freezers has also been used for the preservation of cell-based products such as red blood cells [71-73]. It has to be taken into account that cell-based products half-life is diminished in these temperatures due to the slow and progressive recrystallization phenomenon, that will occur above the $\mathrm{Tg}$, for this reason it is important to establish a storage half-life of cell-based products in these freezers. The FDA approved the storage of red blood cells in $-80^{\circ} \mathrm{C}$ freezers for ten years for their use in clinics [10]. Moreover, a successful storage of human and porcine pluripotent stem cells in suspension at $-80^{\circ} \mathrm{C}$ for at least one year has been achieved recently [72]. However, the detrimental effect of the storage above the $\mathrm{Tg}$ was reported in more complex biosystems. Cell recovery of microencapsulated liver spheroids was decreased gradually after the cryopreservation at $-80^{\circ} \mathrm{C}$ after just few weeks. In the same work, microencapsulated liver spheroids were cryopreserved and stored at vapor phase nitrogen for a year, and high cell recoveries were achieved [74]. In this way, the emergence of $-120^{\circ} \mathrm{C}$ freezer should have promoted new works in which their effectiveness for different cell products was assessed, however, there is still little information published for the cryopreservation of the cell-based products with these electric freezers.

\subsection{Thawing}

Sample thawing is as important as cooling in order to achieve a successful cryopreservation. In warming, cells can suffer the same injury they experience in cooling. The created ice nuclei during cooling could grow and reorganize to form more ice crystals extracellularly. Similarly, small ice nuclei that have been formed during cooling intracellularly and that were not big enough to exert damage, could grow and cause mechanical damage inside cells $[75,76]$. Some authors have postulated that thawing processes are more crucial than the cooling itself [77]. Although this was postulated after the vitrification of oocytes, it highlights the importance of thawing for the successful recovery of cells. In this sense, as processes occurring throughout warming of slowly cooled samples are not easy to predict, fast thawing has been favored in order to prevent the feared ice crystal growth. The most used way to thaw samples is by their immersion in a water bath at $37^{\circ} \mathrm{C}$ obtaining good results over decades $[13,14,35,36,38,64]$. However, as sample contact with water could produce 
contamination, new machines have been developed to eliminate that risk. With their use (e.g., VIA Thaw), control of thawing rates and samples temperature end point fixing (0$4^{\circ} \mathrm{C}$ ) are possible, which would prevent samples from reaching high temperatures and be damaged by CPA toxicity. By contrast, the fast thawing of vitrified tissues has been developed using radiofrequency-excited mesoporous silica-coated iron oxide nanoparticles. In this work, blood vessels were thawed homogenously with the inductive heating of these nanoparticles obtaining slight improvements in viability to the conventional thawed samples [78]. Regardless of the technique used for sample thawing, the monitoring of temperature by thermocouples is highly useful to assess thawing reproducibility in the cryopreservation field, and should always be measured.

Slow thawing of samples has also been proposed to thaw cryopreserved cellbased products. With this procedure is hypothesized that the osmotic re-equilibration mechanisms will take place during the process, achieving beneficial effects in cell recovery after thawing. However, the longer exposure time to high CPA concentrations at high subzero temperatures could also be detrimental. Few studies thaw cell-based products slowly, but they are worth to mentioning for their positive results. Kilbride et al. cryopreserved a 2.3-liter biomass of microencapsulated liver spheroids to assess whether a bioartificial liver device could be preserved [79]. In this work, thermocouples were placed in different layers of the biomass, and a stepwise manner thawing was performed, assessing the thawing profile of the different layers of the biomass (Figure 5). Differences in cell function and cell recovery were achieved between layers, demonstrating that the achievement of homogenous heat transfer in large volumes is still challenging. However, it is remarkable that a successful and practical thawing was completed with the slow thawing procedure. Furthermore, slow thawing has been related to the improved preservation of minipig iliac arteries [80]. Microfractures and the accumulation of fluid within the arterial tissue provoked during cryopreservation were prevented with slow thawing. Even if cell recovery was not determined in this work, it indicates that slow thawing may produce less structural damage in tissues. However, although these works demonstrated that slow thawing could be an appropriate approach for the thawing of large samples or tissues, the fast thawing is the preferred method for recovering samples, reminding us that thawing is also crucial to take into consideration in slow freezing cryopreservation. 


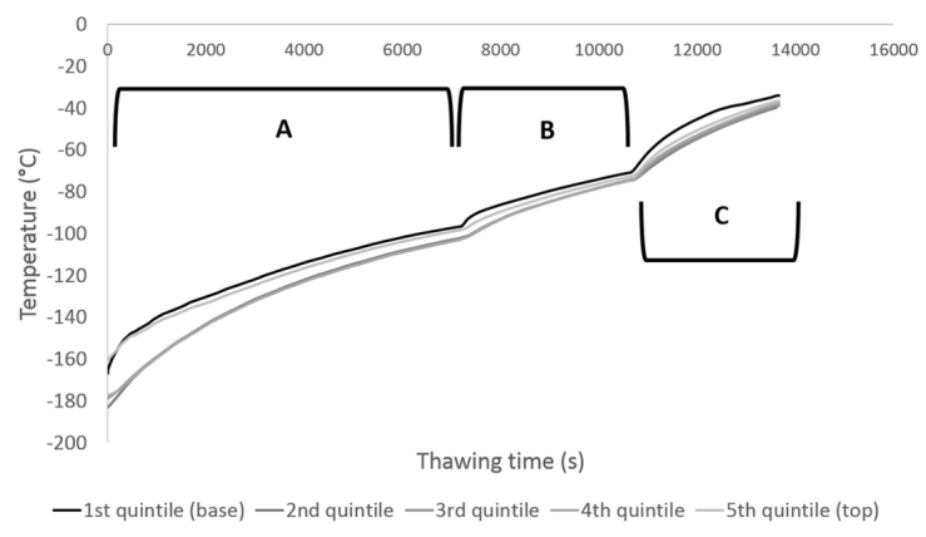

Figure 5: Warming profiles experienced during warming of the large volume cryopreservation cylindrical chamber. Thermocouples were placed at the bottom of the biomass (black) and the top of the biomass (lightest grey), as well as three others equidistant apart between the bottom and top following a straight line through the deepest part of the sample (dark to lighter grey). Section A demarks warming in the $-80^{\circ} \mathrm{C}$ freezer, section $\mathrm{B}$ thawing in the $-30^{\circ} \mathrm{C}$ freezer, and section $\mathrm{C}-10^{\circ} \mathrm{C}$ in the Planer controlled rate freezer. (Figure as originally published in [79])

\subsection{CPA removal}

Lastly, after all ice crystals are thawed and before samples are ready to be used, CPAs removal is needed in order to prevent their toxic effects on cells. Moreover, if the product is implanted directly into humans without CPAs removal, it could produce adverse effects such as those produced by DMSO [26]. This step, like CPA addition, is dependent on each cell type and sample volume, and should be optimized for each sample. Normally, after thawing samples are not warmed until almost or all CPAs are removed, due to their toxic effects in cells in supra zero temperatures [17]. Also, CPA removal is performed gradually, with the addition of decreasing osmotic solutions step by step: firstly not to exert an excessive osmotic stress to cells, and secondly, to remove CPAs continuously. Lawson et al. studied a mathematical model for the addition of CPA and its removal in cell-based systems, and demonstrated that the addition and removal of CPAs should be performed at low temperatures [54]. Also, they employed gradual CPA addition and removal protocols showing the usefulness of the mathematical model for the design of CPA addition and removal protocols. As mentioned with the thawing, not optimizing removal of CPAs could negatively affect the general outcome of the slow freezing cryopreservation of cell-based products. 


\section{Slowly cryopreserved microencapsulated cells}

Tissue engineering has evolved enormously in recent decades due to the technological advances and has started to be used in clinics. For this reason, several researchers require a tissue-banking system to prepare for the rising demand of tissues, cell-based products or organs. The only method to preserve cell-based systems or products for long periods is with the use of low temperatures. Thus, the efforts to cryopreserve cell-based products made of natural polymers (e.g., agarose, hyaluronic acid, fibrin or collagen) or synthetic polymers (e.g., PEG) have linearly grown with its reflection in more publications in last decades [22,30,47,79,81]. Alginate has been one of the most often used polysaccharides to form cellularized bioscaffolds due to its potential as sustained drug delivery or cell delivery systems for the treatment of different diseases (e.g., diabetes, hepatic diseases, neurodegenerative or cancer among others) [82-85]. Cells are embedded in the biocompatible matrix of alginate, and sometimes covered by a semipermeable membrane, such as poly-L-lysine. This outer membrane protects the inner cells from the host's immune system and the mechanical stress, enabling the transplantation of these cell-based products (Figure 6). However, although several in vivo experiments [86-88] and clinical trials have been investigated with alginate microcapsules for the treatment of diverse diseases such as Diabetes [8991]or Parkinson's [92], their cryopreservation using slow freezing still needs further research to reach the clinics, get approved by the governmental agencies or commercially available. Thus, in order to understand and facilitate the future research on the slow freezing of microencapsulated cells, the existing studies in the area will be summarized below.

\subsection{Cryoprotective effect of alginate}

Different studies have determined the hydrogels cryoprotective effect in the cryopreservation of microencapsulated mammalian cells [93-99], and in plant cryopreservation [100]. Different mechanisms have been related to post-thaw cell function improvement on the cryopreservation of microencapsulated cells: the influence of the polymeric matrix on extracellular ice formation [101], initiation of intracellular ice formation [102,103], buffering the CPA diffusion or protection against apoptosis [104]. For that reason, the beneficial effect of alginate encapsulation in slow freezing cryopreservation was compared to free cells after thawing (Tables 3-6). 
Cell suspension in ultrapure

alginate
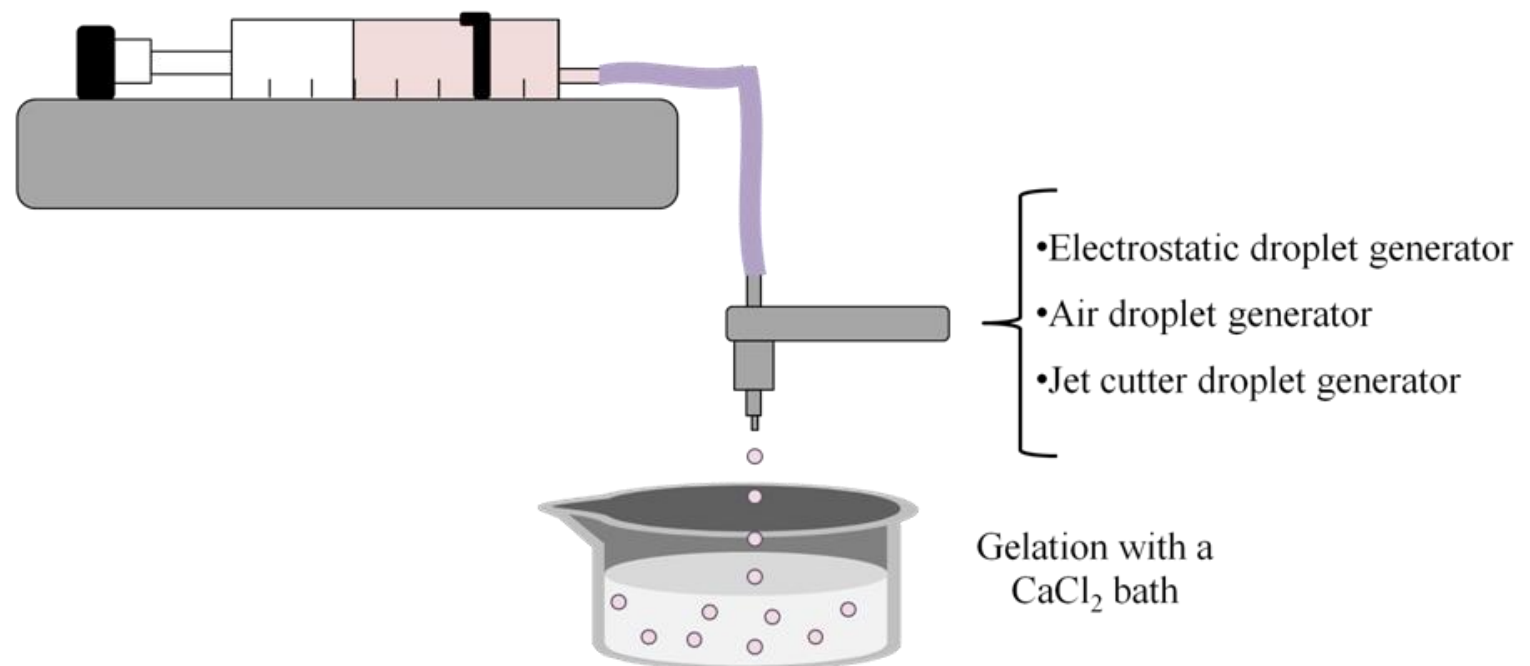

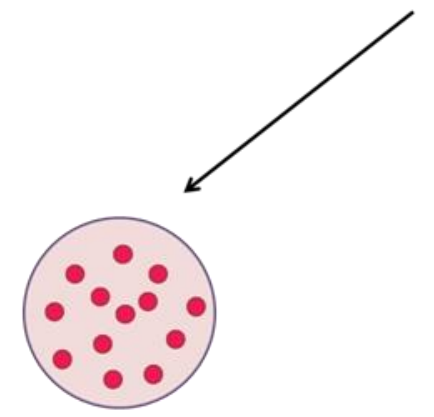

Alginate microcapsules with cells embedded

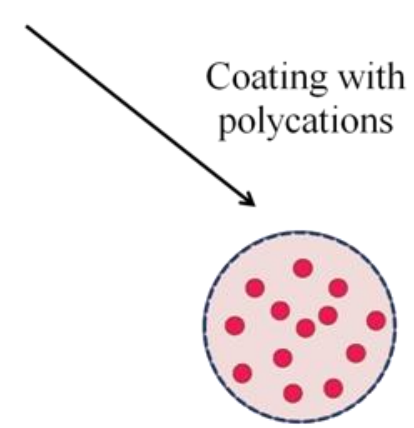

Alginate microcapsules coated to control cell and drug delivery

Figure 6: Scheme of the microencapsulation process. Cells are suspended in ultrapure alginate (1-3\%(w/v)) obtaining a viscous solution with variable cell densities depending on cell type and therapeutic application $\left(1-5 \times 10^{6}\right.$ cells $/ \mathrm{mL}$ alginate). This cell suspension is next extruded through a needle in which suspensions droplets can be generated by different encapsulation technologies (electrostatic, air or jet cutter) which are solidified in a bivalent cations bath, such as calcium chloride. The generated microcapsules can be directly used for therapeutic applications, or coated with polycationic molecules, such as poly-L-lysine. 
Table 3: Encapsulated and cryopreserved insulin-secreting cells

\begin{tabular}{ccccc}
$\begin{array}{c}\text { Cell Type } \\
(\text { Biomaterial) }\end{array}$ & $\begin{array}{c}\text { CPA } \\
\text { solution }\end{array}$ & Cryopreservation protocol & $\begin{array}{c}\text { Frozen } \\
\text { volume }\end{array}$ & Main results \\
\hline
\end{tabular}

\begin{tabular}{|c|c|c|}
\hline $\begin{array}{c}\text { Rat islets } \\
\text { (Alg-PLL-Alg) }\end{array}$ & $\begin{array}{c}15,6 \% \text { DMSO }+7.5 \% \\
\text { FCS }\end{array}$ & $\begin{array}{l}\text { Two different cooling protocols: linear cooling at - } \\
1{ }^{\circ} \mathrm{C} / \text { min with a Nalgene freezing container from } 4^{\circ} \mathrm{C} \text { to - } \\
70^{\circ} \mathrm{C} \text {; and linear cooling from } 4^{\circ} \mathrm{C} \text { to }-45^{\circ} \mathrm{C} \text { at }-0.2^{\circ} \mathrm{C} / \mathrm{min} \\
\text { (ice nucleation induced at }-7.5^{\circ} \mathrm{C} \text { ) and stored in } \mathrm{LN} \text {. FT }\end{array}$ \\
\hline $\begin{array}{l}\text { Porcine islets } \\
\text { (Alg-PLL-Alg) }\end{array}$ & $\begin{array}{c}15,6 \% \mathrm{DMSO}+7.5 \% \\
\text { FBS }\end{array}$ & $\begin{array}{l}\text { Two different cooling protocols: cooling with a CRF } \\
\text { until }-7.5^{\circ} \mathrm{C} \text { (where ice nucleation was induced), } 15 \mathrm{mins} \\
\text { held, cooled at }-0.2^{\circ} \mathrm{C} / \mathrm{min} \text { to }-45^{\circ} \mathrm{C} \text {; cooling at }-1^{\circ} \mathrm{C} / \mathrm{min} \\
\text { in a Nalgene freezing container until }-70^{\circ} \mathrm{C} \text { and stored in } \\
\text { LN. FT }\end{array}$ \\
\hline $\begin{array}{c}\text { Rat islets } \\
\text { (Alg-PLL-Alg) }\end{array}$ & $\begin{array}{c}11,7 \% \text { DMSO }+7,5 \% \\
\text { FBS }\end{array}$ & $\begin{array}{l}\text { Two different cooling protocols: } 4^{\circ} \mathrm{C} \text { to } 0^{\circ} \mathrm{C} \text { at } 5 \mathrm{C} / \mathrm{min} \text {, } \\
\text { hold at } 0^{\circ} \mathrm{C} 20 \mathrm{~min} \text {, cooling from } 0^{\circ} \mathrm{C} \text { to }-80^{\circ} \mathrm{C} \text { at } \\
1 \mathrm{C}^{\circ} / \mathrm{min} ; 4^{\circ} \mathrm{C} \text { to } 0^{\circ} \mathrm{C} \text { at a rate of } 5^{\circ} \mathrm{C} / \mathrm{min} \text {, hold } 20 \mathrm{~min} \text {, } \\
\text { cooling from } 0^{\circ} \mathrm{C} \text { to }-40^{\circ} \mathrm{C} \text { at } 0.3 \mathrm{C} / \mathrm{min} \text {, and cooled } \\
\text { from }-40^{\circ} \mathrm{C} \text { to }-80^{\circ} \mathrm{C} \text { at } 1 \mathrm{C} / \mathrm{min} \text {, stored in } \mathrm{LN} \text {. FT }\end{array}$ \\
\hline
\end{tabular}

$1.8 \mathrm{ml}$

Cryopreserved encapsulated islets (with induced ice nucleation protocol) were able to maintain in vitro glucose response, and also maintained normoglycemia up to 90 days in induced diabetic mice.

Only cryopreserved encapsulated islets with induced ice nucleation were able to maintain glucose challenge, and $66 \%$ of the induced diabetic mice recovered normoglycemia for 90 days with cryopreserved encapsulated islets.

Cryopreserved encapsulated islets (wherever the cooling protocol) were able to maintain insulin secretion. Cryopreserved encapsulated islet maintained normoglycemia in diabetic mice for 90 days.

Cooling with a CRF and stored in LN. FT

Rat islets

$10 \%$ DMSO $+10 \%$

FBS

Murine insulinoma

$10 \%$ DMSO

$4^{\circ} \mathrm{C} 10 \mathrm{~min}$, cooling at $-1^{\circ} \mathrm{C} / \mathrm{min}$ with Mr. Frosty container in a $-80^{\circ} \mathrm{C}$ freezer, and stored at $-150^{\circ} \mathrm{C}$. FT
Rat normoglycemia was achieved with cryopreserved encapsulated islet for 460 days. After graft retrieval similar insulin secretion in vitro of cryopreserved encapsulated islets to non-cryopreserved group.

Islet metabolism maintained in encapsulated cells by either slow freezing or vitrification. Insulin secretion only maintained by slow freezing.
$2011^{109}$

$2012^{110}$

\footnotetext{
CPA solution: cryoprotectant solution; Alg: Alginate; PLL: poly-L-lysine; MCP: measured cooling profile; LN: liquid nitrogen; VN: vapor nitrogen; FT; fast thawing; DMSO:
}

dimethylsulfoxide; FBS: fetal bovine serum; FCS: fetal calf serum. 
In one of the first studies of microencapsulated and cryopreserved cells, microencapsulated rat islets were compared to free islets for their cryopreservation [93]. To that aim, microencapsulated islets were frozen with $15.6 \%(\mathrm{v} / \mathrm{v})$ DMSO using two protocols: linear cooling with a Nalgene freezing container at $-1{ }^{\circ} \mathrm{C} / \mathrm{min}$ and stored in liquid nitrogen; and another linear cooling at $-0.2^{\circ} \mathrm{C} / \mathrm{min}$, in which ice nucleation was induced at $-7.5^{\circ} \mathrm{C}$, and plunged in liquid nitrogen. After fast thawing, cryopreserved microencapsulated islets did not display differences compared to the non-cryopreserved microencapsulated islets in insulin response to high glucose. By contrast, cryopreserved free islets showed a significantly lower response to high glucose, and many islets were lost during the cryopreservation. Furthermore, the cryopreserved microencapsulated islets were able to maintain normoglycemia up to 90 days in induced diabetic mice, whereas the cryopreserved free islets maintained it for only few days. That work demonstrated for the first time that alginate encapsulation could protect cells in the freeze-thaw processes. Moreover, Matsumoto et al. tested the advantages of alginate encapsulation for the cryopreservation of rat pheochromocytoma cells [94]. In that study, the cooling and thawing rates were studied in free and microencapsulated cells. Even it was one of the first demonstrations of cryopreservation with microencapsulated cells, key variables such as the observation of ice growth on the freeze-thaw process, and the latent heat release on cooling were studied. As in Mazur's 2-factor hypothesis, they also showed the inverted " $U$ " effect in the post-thaw viabilities of cryopreserved microencapsulated cells with different cooling rates. In this case, slow cooling rates of 0.5 or $1^{\circ} \mathrm{C} / \mathrm{min}$ demonstrated higher viabilities in terms of dopamine secretion and trypan blue exclusion assay in microencapsulated rat pheochromocytoma cells (Figure 7A-B). Interestingly, the fast cooling profiles did not prevent the ice growth within the microcapsules around $-8^{\circ} \mathrm{C}$, whereas the $1^{\circ} \mathrm{C} / \mathrm{min}$ did not show ice growth within the microcapsules at that temperature (Figure 7C). Moreover, in slower cooling rates $(0.5$ or $1{ }^{\circ} \mathrm{C} / \mathrm{min}$ ) less latent heat was released from cryopreserved microencapsulated cells compared to free cells (Figure 7D). Authors correlated the higher cell viabilities in cryopreserved microencapsulated cells with an increase of unfrozen water inside the microcapsule and the intracellular space, which could also explained by suitable cell and microcapsule dehydration during cooling. In another study with microencapsulated rat islets, the benefit of alginate encapsulation in cryopreservation was again confirmed [95]. Samples were cooled with $11.7 \%$ (v/v) DMSO using two different stepwise protocols in a controlled rate freezer $(\mathrm{CRF})$ and stored in liquid nitrogen. The 
microencapsulated islets displayed similar insulin secretion as free islets, but after cryopreservation (regardless of the cooling protocol), only the microencapsulated islets were able to maintain the insulin response. It was also demonstrated that cryopreserved microencapsulated rat islets with the protocol, cooled from $0^{\circ} \mathrm{C}$ to $-80^{\circ} \mathrm{C}$ at $1^{\circ} \mathrm{C} / \mathrm{min}$ and stored in liquid nitrogen, normalized the metabolic blood glucose of diabetic mice for 90 days, whereas the free cryopreserved rat islets only normalized glucose for a few days. Lastly, brain cell neurospheres were also cryopreserved within alginate capsules to improve cell function and reduce cell defragmentation after thawing [96]. After demonstrating that neurosphere encapsulation had no impact on cell function, free and microencapsulated neurospheres were cryopreserved with a $\mathrm{CRF}$ at $-1^{\circ} \mathrm{C} / \mathrm{min}$ to $-80^{\circ} \mathrm{C}$ and stored in the vapor phase of liquid nitrogen. Different CPA solutions were also used; a complete medium consisted of 10\% (v/v) DMSO and 10\% FBS, and CryostorCS10® solution which also contains $10 \%$ DMSO. After fast thawing, microencapsulated and cryopreserved neurospheres, independent of the CPA solution used, displayed better viabilities with less cell defragmentation compared to cryopreserved free cells. Moreover, Cryostor-CS10® provided further cryoprotection for both free and microencapsulated neurospheres compared to the other CPA solutions. Altogether these studies, demonstrated that alginate encapsulation could have a protective effect in the cryopreservation of diverse cell types displaying fewer defragmented cells and enhancing cell function after thawing.

\subsection{Islets and insulin-secreting $\beta$-cells}

Most efforts of cell encapsulation are aimed at treating type I diabetes, a disease that develops as a consequence of the destruction of pancreatic islets including the insulin-secreting $\beta$-cells. Cell encapsulation research has focused on restoring and regulating the insulin supply, and many clinical trials were performed to translate the technology to the clinic [105-107]. In order to reduce cost and provide cell-based product banks, the preservation of microencapsulated islets and B-cells have also been investigated with the slow freezing in the last two decades [93,95,108-110] (Table 3).

In the first study performed with cryopreserved microencapsulated islets, Inaba et al. demonstrated the benefits of alginate encapsulation in islets storage [93]. Next, the same group studied the slow freezing of porcine microencapsulated islets with $15.6 \%$ (v/v) DMSO in two diverse cooling protocols [108]. After fast thawing, only the batches frozen with induced ice nucleation were able to respond to static high glucose and 
A

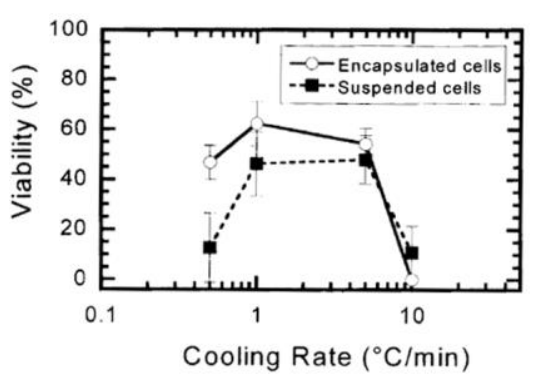

C

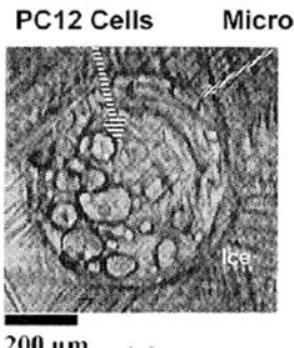

(a)

\section{apsule}

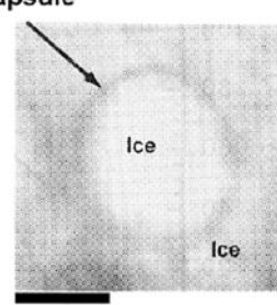

$200 \mu \mathrm{m}$ (b)

$1^{\circ} \mathrm{C} / \mathrm{min},-8^{\circ} \mathrm{C}$

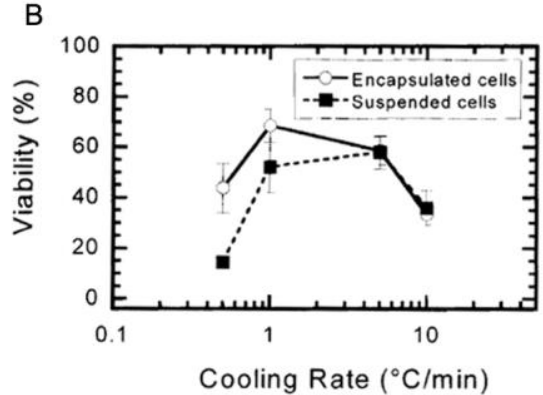

D

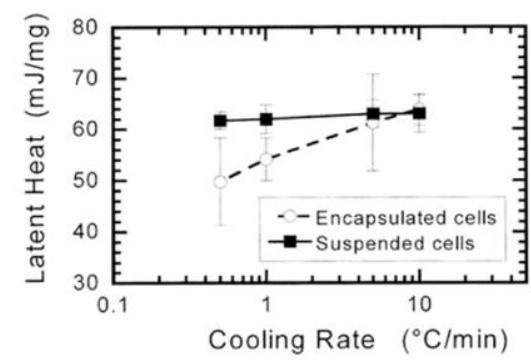

Figure 7: Cooling rate effects on cell function after thawing and ice nucleation temperatures. Viability and cooling rate relationship determined by dopamine secretion (A) or trypan blue exclusion assay (B). C) Cryomicroscopy images of microencapsulated P12 cells with slow (a) and fast (b) cooling rates showing differences in ice nucleation temperatures. Scale bar: $200 \mu \mathrm{m}$. Reprinted from Improvement in the Viability of Cryopreserved Cells By Microencapsulation, Matsumoto Y, Morinaga Y, Ujihira M, Oka K, Tanishita K, JSME international Journal Series C, 384-90, Copyright (2018), with permission from JSME. 
Table 3: Encapsulated and cryopreserved insulin-secreting cells

\begin{tabular}{ccccc}
$\begin{array}{c}\text { Cell Type } \\
(\text { Biomaterial) }\end{array}$ & $\begin{array}{c}\text { CPA } \\
\text { solution }\end{array}$ & Cryopreservation protocol & $\begin{array}{c}\text { Frozen } \\
\text { volume }\end{array}$ & Main results \\
\hline
\end{tabular}

\begin{tabular}{|c|c|c|}
\hline $\begin{array}{c}\text { Rat islets } \\
\text { (Alg-PLL-Alg) }\end{array}$ & $\begin{array}{c}15,6 \% \text { DMSO }+7.5 \% \\
\text { FCS }\end{array}$ & $\begin{array}{l}\text { Two different cooling protocols: linear cooling at - } \\
1{ }^{\circ} \mathrm{C} / \text { min with a Nalgene freezing container from } 4^{\circ} \mathrm{C} \text { to - } \\
70^{\circ} \mathrm{C} \text {; and linear cooling from } 4^{\circ} \mathrm{C} \text { to }-45^{\circ} \mathrm{C} \text { at }-0.2^{\circ} \mathrm{C} / \mathrm{min} \\
\text { (ice nucleation induced at }-7.5^{\circ} \mathrm{C} \text { ) and stored in } \mathrm{LN} \text {. FT }\end{array}$ \\
\hline $\begin{array}{l}\text { Porcine islets } \\
\text { (Alg-PLL-Alg) }\end{array}$ & $\begin{array}{c}15,6 \% \mathrm{DMSO}+7.5 \% \\
\text { FBS }\end{array}$ & $\begin{array}{l}\text { Two different cooling protocols: cooling with a CRF } \\
\text { until }-7.5^{\circ} \mathrm{C} \text { (where ice nucleation was induced), } 15 \mathrm{mins} \\
\text { held, cooled at }-0.2^{\circ} \mathrm{C} / \mathrm{min} \text { to }-45^{\circ} \mathrm{C} \text {; cooling at }-1^{\circ} \mathrm{C} / \mathrm{min} \\
\text { in a Nalgene freezing container until }-70^{\circ} \mathrm{C} \text { and stored in } \\
\text { LN. FT }\end{array}$ \\
\hline $\begin{array}{c}\text { Rat islets } \\
\text { (Alg-PLL-Alg) }\end{array}$ & $\begin{array}{c}11,7 \% \text { DMSO }+7,5 \% \\
\text { FBS }\end{array}$ & $\begin{array}{l}\text { Two different cooling protocols: } 4^{\circ} \mathrm{C} \text { to } 0^{\circ} \mathrm{C} \text { at } 5 \mathrm{C} / \mathrm{min} \text {, } \\
\text { hold at } 0^{\circ} \mathrm{C} 20 \mathrm{~min} \text {, cooling from } 0^{\circ} \mathrm{C} \text { to }-80^{\circ} \mathrm{C} \text { at } \\
1 \mathrm{C}^{\circ} / \mathrm{min} ; 4^{\circ} \mathrm{C} \text { to } 0^{\circ} \mathrm{C} \text { at a rate of } 5^{\circ} \mathrm{C} / \mathrm{min} \text {, hold } 20 \mathrm{~min} \text {, } \\
\text { cooling from } 0^{\circ} \mathrm{C} \text { to }-40^{\circ} \mathrm{C} \text { at } 0.3 \mathrm{C} / \mathrm{min} \text {, and cooled } \\
\text { from }-40^{\circ} \mathrm{C} \text { to }-80^{\circ} \mathrm{C} \text { at } 1 \mathrm{C} / \mathrm{min} \text {, stored in } \mathrm{LN} \text {. FT }\end{array}$ \\
\hline
\end{tabular}

$1.8 \mathrm{ml}$

Cryopreserved encapsulated islets (with induced ice nucleation protocol) were able to maintain in vitro glucose response, and also maintained normoglycemia up to 90 days in induced diabetic mice.

Only cryopreserved encapsulated islets with induced ice nucleation were able to maintain glucose challenge, and $66 \%$ of the induced diabetic mice recovered normoglycemia for 90 days with cryopreserved encapsulated islets.

Cryopreserved encapsulated islets (wherever the cooling protocol) were able to maintain insulin secretion. Cryopreserved encapsulated islet maintained normoglycemia in diabetic mice for 90 days.

Cooling with a CRF and stored in LN. FT

Rat islets

$10 \%$ DMSO $+10 \%$

FBS

Murine insulinoma

$10 \%$ DMSO

$4^{\circ} \mathrm{C} 10 \mathrm{~min}$, cooling at $-1^{\circ} \mathrm{C} / \mathrm{min}$ with Mr. Frosty container in a $-80^{\circ} \mathrm{C}$ freezer, and stored at $-150^{\circ} \mathrm{C}$. FT
Rat normoglycemia was achieved with cryopreserved encapsulated islet for 460 days. After graft retrieval similar insulin secretion in vitro of cryopreserved encapsulated islets to non-cryopreserved group.

Islet metabolism maintained in encapsulated cells by either slow freezing or vitrification. Insulin secretion only maintained by slow freezing.
$2011^{109}$

$2012^{110}$

\footnotetext{
CPA solution: cryoprotectant solution; Alg: Alginate; PLL: poly-L-lysine; MCP: measured cooling profile; LN: liquid nitrogen; VN: vapor nitrogen; FT; fast thawing; DMSO:
}

dimethylsulfoxide; FBS: fetal bovine serum; FCS: fetal calf serum. 
isobutylmethylxanthine challenge, demonstrating the importance of inducing ice nucleation. The intraperitoneal transplantation into diabetic mice of cryopreserved microencapsulated islets was performed only with the frozen batches in which ice nucleation was induced and, $60 \%$ of recipients recovered normoglycemia compared to the $91 \%$ of the non-cryopreserved group showing that cryopreservation was effective. Moreover, freezing procedure did not alter capsule surface, and did not display fibrotic overgrowth during transplantation. In another study, the microencapsulated and cryopreserved islet function was assessed 460 days after the transplantation [109]. Rat normoglycemia was assured with the microencapsulated and cryopreserved islets with similar insulin secretion after graft retrieval compared to the microencapsulated and non-cryopreserved group. Cryopreservation of a pancreatic substitute consisted of microencapsulated murine insulinoma $\beta$ TC-tet cells was also performed comparing slow freezing to vitrification [110]. For the slow freezing, microencapsulated cells were cooled at $-1{ }^{\circ} \mathrm{C} / \mathrm{min}$ with a Mr. Frosty Freezing container, and stored in liquid nitrogen. After fast thawing of samples, and using a $\mathrm{C}^{13}$ nuclear magnetic resonance and isotopomer analysis, the metabolism was maintained in microencapsulated $\beta$ TC-tet cells by either slow freezing or vitrification. By contrast, insulin secretion was maintained only after slow freezing, displaying the advantages of slow freezing compared to vitrification in the storage of microencapsulated $\beta$ TC-tet cells.

\subsection{Mesenchymal stem cells (MSCs)}

MSCs are being studied intensively due to their advantageous properties for cellbased therapies. MSCs can differentiate into three different lineages (e.g., osteogenic, adipogenic and chondrogenic) making them appropriate for regenerative medicine. Moreover, this cell type can immune-modulate the environment, avoiding the immune system reaction, which is desirable for cellular implants [111,112]. Their encapsulation in hydrogels or alginate capsules has been studied extensively [84,113-115], and their storage also investigated in the last few years (Table 4).

In the first study with slow cryopreservation of microencapsulated MSCs, Pravdyuk et al. considered the influence of DMSO concentration (5-10\% v/v) and three cooling protocols (e.g., two slow and a rapid cooling protocols) in the post-thaw outcome of microencapsulated human MSCs [13]. It was demonstrated that DMSO at $10 \%$ was the optimal concentration maintaining viability and metabolic activity in microencapsulated MSCs after thawing. The second cooling protocol, with induced ice 
Table 4: Encapsulated and cryopreserved mesenchymal stem cells

\begin{tabular}{|c|c|c|c|c|c|}
\hline $\begin{array}{c}\text { Cell Type } \\
\text { (Biomaterial) }\end{array}$ & $\begin{array}{c}\text { CPA } \\
\text { solution }\end{array}$ & Cryopreservation protocol & $\begin{array}{l}\text { Frozen } \\
\text { volume }\end{array}$ & Main results & Year ${ }^{\text {ref }}$ \\
\hline $\begin{array}{l}\text { Human MSCs } \\
\quad \text { (Alg) }\end{array}$ & $\begin{array}{l}5 \text { or } 10 \% \text { DMSO }+10 \% \\
\text { FCS }\end{array}$ & $\begin{array}{c}4^{\circ} \mathrm{C} 15 \mathrm{~min} \text { and } 3 \text { different profiles: } 1 \text { ) linear }-1^{\circ} \mathrm{C} / \mathrm{min} \text { to } \\
-80^{\circ} \mathrm{C} ; 2 \text { ) cooled at }-1^{\circ} \mathrm{C} / \mathrm{min} \text { from } 0 \text { to }-7^{\circ} \mathrm{C} \text { (where ice } \\
\text { nucleation was induced), then cooled at }-1^{\circ} \mathrm{C} / \mathrm{min} \text { to - } \\
40^{\circ} \mathrm{C} \text {, and a }-10^{\circ} \mathrm{C} / \mathrm{min} \text { until }-80^{\circ} \mathrm{C} ; 3 \text { ) one stage rapid } \\
\text { cooling by direct immersion in LN. All stored in LN and } \\
\text { FT }\end{array}$ & $1 \mathrm{ml}$ & $\begin{array}{l}10 \% \text { DMSO in CPA solution displayed better results than 5\% DMSO. Second } \\
\text { protocol, which included induced ice nucleation, showed the best viability and } \\
\text { metabolic activity after thawing. }\end{array}$ & $2013^{13}$ \\
\hline $\begin{array}{l}\text { Primate MSCs } \\
\qquad(\mathrm{Alg})\end{array}$ & $\begin{array}{l}10 \% \mathrm{DMSO}+17.5 \% \\
\text { FBS }\end{array}$ & $\begin{array}{c}4^{\circ} \mathrm{C} 12 \mathrm{~min} \text {, cooling at }-1^{\circ} \mathrm{C} / \mathrm{min} \text { with an isopropanol } \\
\text { progressive freezing container, }-80^{\circ} \mathrm{C} \text { overnight and } \\
\text { stored at }-150^{\circ} \mathrm{C} \text {. FT }\end{array}$ & $2 \mathrm{ml}$ & $\begin{array}{l}\text { Encapsulated and cryopreserved MSCs showed better metabolic activities } \\
\text { compared to encapsulated MSCs, cultured 24hours and cryopreserved ones. }\end{array}$ & $2014^{116}$ \\
\hline $\begin{array}{l}\text { Murine MSCs } \\
\text { (Alg-PLL-Alg) }\end{array}$ & $\begin{array}{l}\text { Different CPAs }+10 \% \\
\text { FBS }\end{array}$ & $\begin{array}{l}\quad 4^{\circ} \mathrm{C} 20 \mathrm{~min} \text {, cooling at }-1^{\circ} \mathrm{C} / \mathrm{min} \text { with a Mr. Frosty } \\
\text { freezing container, }-80^{\circ} \mathrm{C} \text { overnight and stored in LN. FT. }\end{array}$ & $2 \mathrm{ml}$ & $\begin{array}{l}\text { Only cryopreserved encapsulated MSCs with } 10 \% \text { DMSO were able to } \\
\text { maintain metabolic activity, cell viability, EPO secretion in vitro and } \\
\text { hematocrit levels in vivo compared to non-cryopreserved encapsulated MSCs. }\end{array}$ & $2014^{14}$ \\
\hline $\begin{array}{l}\text { Monkey MSCs } \\
\quad \text { (Alg) }\end{array}$ & $\begin{array}{l}10 \% \text { DMSO }+10 \% \\
\text { FBS }\end{array}$ & $\begin{array}{l}\text { Cooling with a Mr. Frosty freezing container, }-80^{\circ} \mathrm{C} \\
\text { overnight and stored at }-150^{\circ} \mathrm{C} \text {. FT }\end{array}$ & $2 \mathrm{ml}$ & $\begin{array}{l}\text { Demonstrated that DMSO concentration could be decreased from } 10 \text { to } 7.5 \% \\
\text { maintaining high cell recoveries after thawing in encapsulated MSCs. }\end{array}$ & $2016^{117}$ \\
\hline
\end{tabular}

\footnotetext{
CPA solution: cryoprotectant solution; Alg: Alginate; PLL: poly-L-lysine; MCP: measured cooling profile; LN: liquid nitrogen; VN: vapor nitrogen; FT; fast thawing; DMSO:

dimethylsulfoxide; FBS: fetal bovine serum; FCS: fetal calf serum; MSCs: mesenchymal stem cells.
} 
nucleation, displayed better viability and metabolic activity, showing the positive effect of induced ice nucleation. Afterwards, Grishkov et al. compared the influence of culture time in microencapsulated primate MSCs before cryopreservation, cryopreserving immediately or after 24 hour incubation of the cell-based products [116]. In this regard, microencapsulated cells were cryopreserved with 10\% (v/v) DMSO and 17.5\% FBS, cooled at $-1{ }^{\circ} \mathrm{C} / \mathrm{min}$ with a Mr. Frosty Freezing container and stored at $-150^{\circ} \mathrm{C}$. After fast thawing and five days culture, the microencapsulated MSCs cryopreserved just after their encapsulation, showed better metabolic activities, and demonstrated that microencapsulated MSC culture time before cryopreservation can impact cell function after thawing. Our group also investigated the cryoprotective effect of different CPAs in the cryopreservation of microencapsulated erythropoietin secreting murine MSCs [14]. Different CPA solutions combining DMSO, trehalose, and glycerol were studied to reduce the concentration of DMSO in cryopreservation. Similar to the previous study, microencapsulated MSCs were cooled at $-1{ }^{\circ} \mathrm{C} / \mathrm{min}$ with a Mr. Frosty Freezing container to $-80^{\circ} \mathrm{C}$, and stored in liquid nitrogen. After sample fast thawing, only cryopreserved microencapsulated MSCs with 10\% (v/v) DMSO were able to maintain metabolic activity, cell viability and erythropoietin secretion compared to non-cryopreserved microencapsulated MSCs. Furthermore, only the 10\% DMSO group was able to maintain the erythropoietin increase in transplanted mice compared to noncryopreserved microencapsulated group. These findings suggest that further investigation should be assessed in the cryopreservation protocol to reduce the used DMSO in the CPA solution. Following this research line, Grishkov et al. studied the DMSO concentration $(2.5-10 \% \mathrm{v} / \mathrm{v})$ in $\mathrm{CPA}$ solution and the pre-freezing DMSO loading time $(0,15,30$ and 45 minutes) of microencapsulated monkey MSCs [117], with similar cooling and thawing processes to their previous study [116]. Independent of the pre-freezing DMSO loading times used, better cell viability (Figure 8A), metabolic activity and membrane integrity were obtained with $7.5 \%$ and $10 \%$ DMSO concentration in the CPA solution. Moreover, also the ice nucleation temperature was studied using cryomicroscopy, demonstrating that different DMSO loading times, and DMSO concentrations in CPA solutions could lead to differences in ice nucleation temperatures (Figure 8B). Interestingly, it was also shown that higher ice-nucleation temperatures $\left(-12.8^{\circ} \mathrm{C}\right)$ impaired the structure of alginate beads after thawing. Altogether, it was demonstrated that DMSO concentration could be decreased from 10 
to $7.5 \%$ maintaining high cell recoveries after thawing in microencapsulated monkey MSCs.

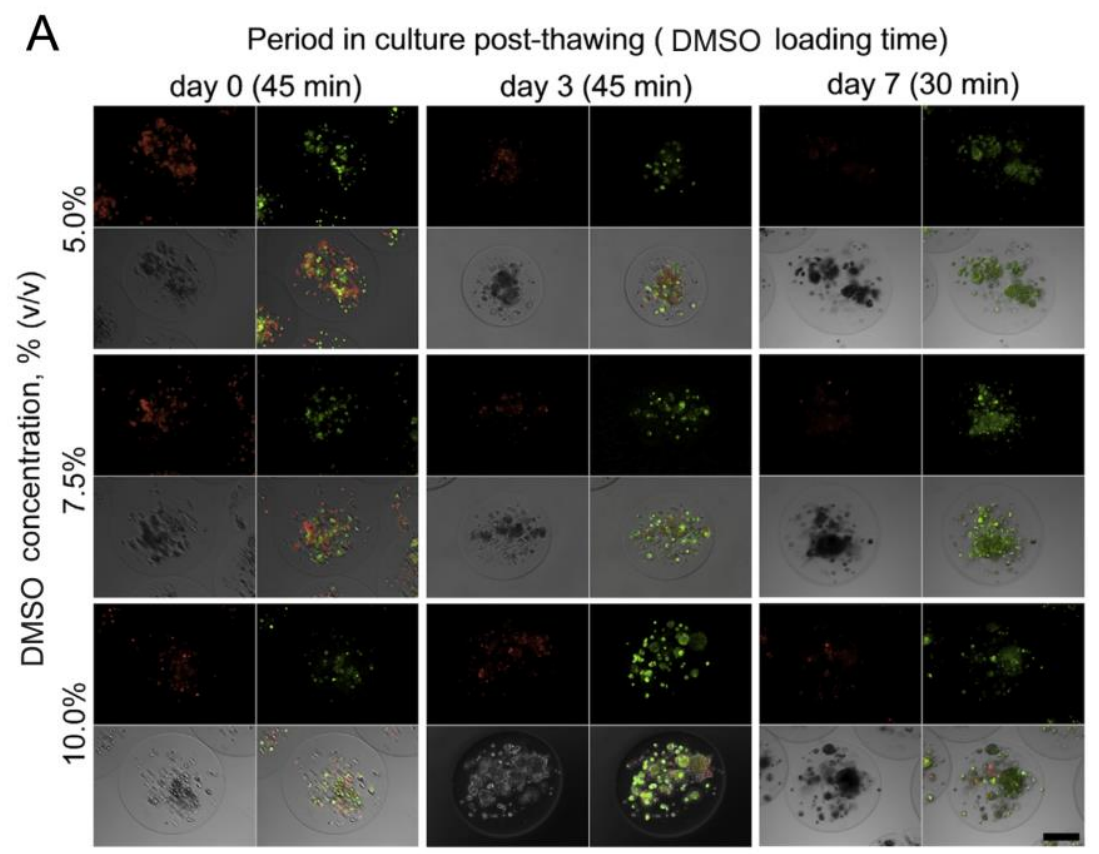

B
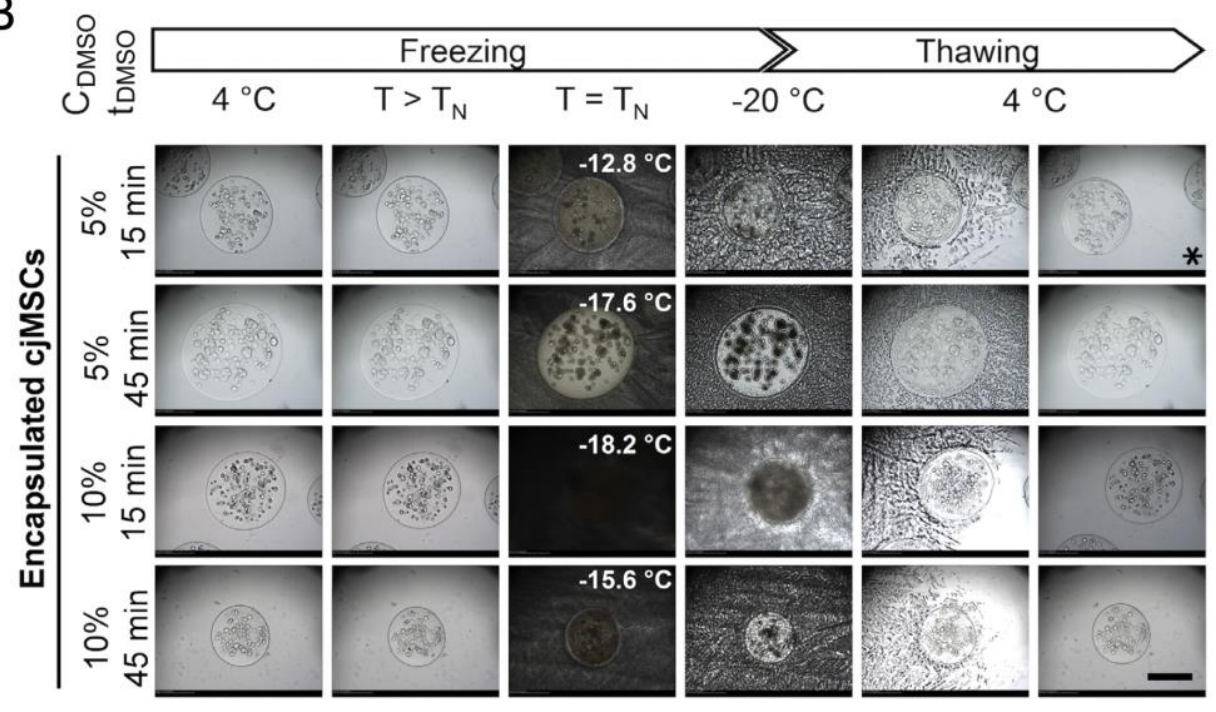

Figure 8: Evaluation of monkey MSCs microencapsulated in alginate beads. A) Live (green)-dead (red) staining of microencapsulated monkey MSCs after thawing following seven days in culture (day 0, day 3, day 7) utilizing 5\%, $7.5 \%$ and $10 \%(\mathrm{v} / \mathrm{v})$ DMSO with $30 \mathrm{~min}$ and $45 \mathrm{~min}$ of pre-loading interval. Freezing was performed using $2.5 \%, 5 \%, 7.5 \%$ and $10 \%(\mathrm{v} / \mathrm{v})$ DMSO with respective pre-freeze loading interval. B) Evaluation of microencapsulated monkey MSCs during freezing/thawing using cryomicroscopy. The temperature value at $\mathrm{T}=\mathrm{TN}$ represents the temperature of ice formation. $\mathrm{T}_{\mathrm{DMSO}}$ represents the DMSO pre-loading interval. The structural damage of the alginate beads rises with rising temperatures of ice formation. Stars depict the process settings that noticeably impaired the homogeneity and/or structure of alginate beads. Scale bars represent $250 \mu \mathrm{m}$. Scale bar: $200 \mu \mathrm{m}$. Reprinted from Multipotent stromal cells derived from common marmoset Callithrix jacchus within alginate 3D environment: Effect of cryopreservation procedures, 71 , O. Gryshkov, N. Hofmann, L. Lauterboeck, D. Pogozhykh, T. Mueller, B. Glasmacher, Cryobiology, 103-111, Copyright (2018), with permission from Elsevier. 
Table 5: Encapsulated and slowly cryopreserved hepatocytes

\begin{tabular}{|c|c|c|c|c|c|}
\hline $\begin{array}{c}\text { Cell Type } \\
\text { (Biomaterial) }\end{array}$ & $\begin{array}{c}\text { CPA } \\
\text { solution }\end{array}$ & Cryopreservation protocol & $\begin{array}{l}\text { Frozen } \\
\text { volume }\end{array}$ & Main results & Year ${ }^{\text {ref }}$ \\
\hline $\begin{array}{l}\text { Rat hepatocytes } \\
\text { (Alg-PLL-Alg) }\end{array}$ & $\begin{array}{l}10 \% \text { DMSO }+20 \% \\
\text { FBS }\end{array}$ & $\begin{array}{c}24 \text { hours at }-70^{\circ} \mathrm{C} \text {, and stored in liquid } \mathrm{LN} \text { for } 7 \text { and } 30 \\
\text { days. FT }\end{array}$ & UNK & $\begin{array}{l}\text { Cryopreserved encapsulated hepatocytes for } 30 \text { days displayed decreased } \\
\text { cell function in vitro and in vivo }\end{array}$ & $1993^{120}$ \\
\hline $\begin{array}{l}\text { Murine hepatocytes } \\
\text { (Alg-cel-PEGC) }\end{array}$ & $10 \%$ DMSO & $4^{\circ} \mathrm{C} 30 \mathrm{~min},-20^{\circ} \mathrm{C} 2 \mathrm{~h},-80^{\circ} \mathrm{C} 24 \mathrm{~h}$ and stored in LN. FT & $1 \mathrm{~mL}$ & $\begin{array}{l}\text { No difference in albumin secretion of fresh and cryopreserved } \\
\text { encapsulated hepatocytes. }\end{array}$ & $2001^{121}$ \\
\hline $\begin{array}{l}\text { Rodent \& human } \\
\text { hepatocytes } \\
\text { (Alg-PLL-Alg) }\end{array}$ & $10 \%$ DMSO & $\begin{array}{c}4^{\circ} \mathrm{C} 12 \mathrm{~min} ; 4.2^{\circ} \mathrm{C} / \mathrm{min} \text { to }-8^{\circ} \mathrm{C} ; 18 \mathrm{~min} \text { hold, } 4.2^{\circ} \mathrm{C} / \mathrm{min} \\
\text { to }-100^{\circ} \mathrm{C} \text { and stored in } \mathrm{LN}(\mathrm{MCP}) . \mathrm{FT}\end{array}$ & $2 \mathrm{~mL}$ & $\begin{array}{l}\text { After xenotransplantation in FLF model mice similar survivals with fresh } \\
\text { or cryopreserved encapsulated rat }(\sim 70 \%) \& \text { human }(\sim 50 \%) \text { hepatocytes. }\end{array}$ & $2005^{122}$ \\
\hline $\begin{array}{l}\text { Porcine hepatocytes } \\
\text { (Alg-PLL-Alg) }\end{array}$ & $10 \%$ DMSO & $\begin{array}{l}1^{\circ} \mathrm{C} / \mathrm{min} \text { from } 4 \text { to } 0^{\circ} \mathrm{C}, 0.5^{\circ} \mathrm{C} / \mathrm{min} \text { to }-11^{\circ} \mathrm{C} \text {, hold } 15 \mathrm{~min} \\
\text { at }-11^{\circ} \mathrm{C}, 3^{\circ} \mathrm{C} / \mathrm{min} \text { to }-80^{\circ} \mathrm{C} \text {, stored in LN. FT. }\end{array}$ & $2 \mathrm{~mL}$ & $\begin{array}{l}\text { After xenotransplantation in FLF model mice similar survivals with fresh } \\
\text { or cryopreserved encapsulated porcine hepatocytes }(\sim 75 \%) \text {. }\end{array}$ & $2009^{123}$ \\
\hline $\begin{array}{l}\text { Human hepatocytes } \\
\text { (Alg-PLL-Alg) }\end{array}$ & $\begin{array}{l}10 \% \text { DMSO }+10 \% \\
\text { FBS }\end{array}$ & $\begin{array}{l}\text { Cooling with an isopropanol progressive freezing } \\
\text { container, }-80^{\circ} \mathrm{C} \text { overnight and stored in LN. FT }\end{array}$ & $2 \mathrm{~mL}$ & $\begin{array}{l}\text { Urea, albumin profile secretion, and hepatocytes gene expression well } \\
\text { maintained. Protein expression increased in CYP3A4. }\end{array}$ & $2010^{124}$ \\
\hline $\begin{array}{l}\text { HepG2 spheroids } \\
\text { (Alg) }\end{array}$ & $12 \% \mathrm{DMSO}$ & $\begin{array}{l}4^{\circ} \mathrm{C} 10 \mathrm{~min}, 8 \mathrm{~min} \text { held at } 0^{\circ} \mathrm{C} \text { and main ramp of } \\
-2 \mathrm{C} / \mathrm{min} \text {; storage in VN (MCP). FT }\end{array}$ & $1.25 \mathrm{~mL}$ & $\begin{array}{l}\text { Same cell function recovery over } 72 \text { hours using a CRF without the use of } \\
\qquad \mathrm{LN} \text { or with it. }\end{array}$ & $2011^{126}$ \\
\hline $\begin{array}{l}\text { HepG2 spheroids } \\
\text { (Alg) }\end{array}$ & $\begin{array}{c}12 \% \text { DMSO + } \\
\text { Cholesterol (INA) }\end{array}$ & $\begin{array}{l}4^{\circ} \mathrm{C} 10 \mathrm{~min}, 8 \text { min held at } 0^{\circ} \mathrm{C} \text { and main ramp of } \\
-2 \mathrm{C} / \min ^{116} \text {; stored in VN (MCP). FT }\end{array}$ & $1.25 \mathrm{~mL}$ & $\begin{array}{l}\text { The INA addition reduced supercooling and also latent cryoinjury, } \\
\text { improving cell numbers, viability, and function in encapsulated HepG2 } \\
\text { spheroids over } 72 \mathrm{~h} \text { post-thawing. }\end{array}$ & $2011^{64}$ \\
\hline $\begin{array}{l}\text { HepG2 spheroids } \\
\text { (Alg) }\end{array}$ & $\begin{array}{c}12 \% \mathrm{DMSO}+ \\
\text { Cholesterol (INA) }\end{array}$ & $\begin{array}{l}4^{\circ} \mathrm{C} 10 \mathrm{~min}, 8 \text { min held at } 0^{\circ} \mathrm{C} \text { and main ramp of } \\
-2 \mathrm{C} / \mathrm{min}^{116} ; \text { stored at }-80^{\circ} \mathrm{C} \text { or VN (MCP). FT }\end{array}$ & $1.25 \mathrm{~mL}$ & $\begin{array}{l}\text { Rapid deterioration in functional recoveries after few weeks stored at - } \\
80^{\circ} \mathrm{C} \text {. VN preserve HepG2 functionality in all study (1 year) }\end{array}$ & $2013^{74}$ \\
\hline $\begin{array}{l}\text { HepG2 spheroids } \\
\text { (Alg) }\end{array}$ & $\begin{array}{l}12 \% \text { DMSO + } 10 \% \text { FFP } \\
+ \text { Catalase \& Trolox }+ \\
\text { Cholesterol (INA) }\end{array}$ & $\begin{array}{l}\text { Held at } 4^{\circ} \mathrm{C} \text {; a simple linear rate was compared with } \\
\text { nonlinear profiles, stored in VN (MCP). FT }\end{array}$ & $\begin{array}{l}0.5 \mathrm{~mL} \\
200 \mathrm{~mL}\end{array}$ & $\begin{array}{l}\text { Similar functional recovery between small and large volume GMP } \\
\text { cryopreservation. Large volume cryopreservation successfully scaled up. }\end{array}$ & $2014^{12}$ \\
\hline $\begin{array}{l}\text { HepG2 spheroids } \\
\text { (Alg) }\end{array}$ & $\begin{array}{l}12 \% \mathrm{DMSO}+\text { IceStart } \\
\text { (INA) }\end{array}$ & $\begin{array}{l}\text { Held at } 4^{\circ} \mathrm{C} ; 1^{\circ} \mathrm{C} / \mathrm{min} \text { to }-80^{\circ} \mathrm{C} \text { and hold } 1 \mathrm{~h} \text {; storage in - } \\
80^{\circ} \mathrm{C} \text { freezer for } 7 \text { days (MCP). FT. }\end{array}$ & $6 \mathrm{~mL}$ & $\begin{array}{l}\text { Small differences between progressive and network solidification in } \\
\text { encapsulated HepG2 function. }\end{array}$ & $2014^{63}$ \\
\hline $\begin{array}{l}\text { HepG2 spheroids } \\
\text { (Alg) }\end{array}$ & $\begin{array}{l}\text { 12\%DMSO + IceStart } \\
\text { (INA) }\end{array}$ & $\begin{array}{c}\text { Held at } 4^{\circ} \mathrm{C} ; 0.3^{\circ} \mathrm{C} / \mathrm{min} \text { to }-100^{\circ} \mathrm{C} \text {; stored in } \mathrm{VN}(\mathrm{MCP}) . \\
\text { FT. }\end{array}$ & $\begin{array}{c}6 \mathrm{~mL} \\
2 \mathrm{~L}\end{array}$ & $\begin{array}{l}\text { Functional differences between studied layers of the large biomass. } \\
\text { Faster thawed layers displayed higher functional recoveries. }\end{array}$ & $2016^{127}$ \\
\hline $\begin{array}{l}\text { HepG2 spheroids } \\
\text { (Alg) }\end{array}$ & $\begin{array}{l}\text { 12\%DMSO + IceStart } \\
\text { (INA) }\end{array}$ & $\begin{array}{c}\text { Held at } 4^{\circ} \mathrm{C} ; 0.3^{\circ} \mathrm{C} / \mathrm{min} \text { to }-100^{\circ} \mathrm{C} \text {; stored in } \mathrm{VN}(\mathrm{MCP}) \text {. } \\
\text { Stepwise ST. }\end{array}$ & $\begin{array}{l}6 \mathrm{~mL} \\
2.3 \mathrm{~L}\end{array}$ & Functional recovery of $2.3 \mathrm{~L}$ biomass after 72 hours. & $2017^{79}$ \\
\hline $\begin{array}{l}\text { Rodent \& human } \\
\text { hepatocytes (Alg) }\end{array}$ & $\begin{array}{c}\text { Different solutions with } \\
\text { DMSO } 10 \%+\text { diverse } \\
\text { additives }\end{array}$ & $\begin{array}{l}4^{\circ} \mathrm{C} 10 \mathrm{~min}, 8 \text { min held at } 0^{\circ} \mathrm{C} \text { and main ramp of } \\
-2 \mathrm{C} / \min ^{116} \text {; stored in VN (MCP). FT }\end{array}$ & $2 \mathrm{~mL}$ & $\begin{array}{l}\text { Best recoveries with Viaspan }{ }^{\circledR} \text {, DMSO10\%, glucose and an anti- } \\
\text { apoptotic factor. }\end{array}$ & $2017^{81}$ \\
\hline
\end{tabular}

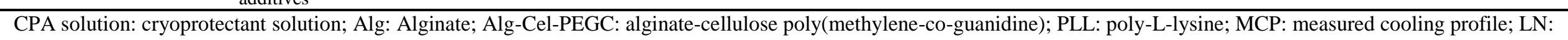

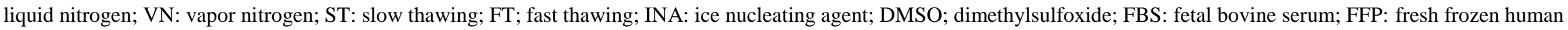
plasma; FLF: fulminant hepatic failure; AAF: anti-apoptotic factor; UNK: unknown. 


\subsection{Hepatocytes for liver diseases}

The encapsulation of hepatocytes has been proposed for supplementing essential functions lacking in some disorders such as fulminant liver failure (FLF). Diverse reports in vivo demonstrated the potential of hepatocyte encapsulation for the FLF treatment $[83,88,118,119]$. Since in FLF the treatment need is immediate, and thus, the banking of these cell-products for the "on demand" access of patients has been extensively studied for two decades mostly with the use of slow freezing cryopreservation (Table 5).

In the first study that was performed with hepatocytes, rat hepatocytes were microencapsulated in alginate-poly-L-lysine-alginate capsules [120]. Microencapsulated hepatocytes were cryopreserved with 10\% (v/v) DMSO keeping cryovials 24 hours at $70^{\circ} \mathrm{C}$, and next stored in liquid nitrogen for 7 and 30 days. After fast thawing, the cryopreserved microencapsulated hepatocytes displayed similar urea synthesis to the non-cryopreserved microencapsulated group. By contrast, cryopreserved microencapsulated hepatocytes for 30 days showed a decrease in protein synthesis. Furthermore, in 30 day cryopreserved microencapsulated hepatocytes, the serum bilirubin levels of transplanted Gunn rats, which have a genetic deficiency of bilirubin glucuronidation, did not decrease as much as in other cryopreserved groups. In this study, the storage time of microencapsulated rat hepatocytes could have affected the post-thaw cell function, indicating that the cryopreservation process requires further. In the early 2000s, murine hepatocytes in alginate-cellulose poly(methylene-co-guanidine) were cryopreserved [121]. The microencapsulated hepatocytes were cooled with $10 \%$ (v/v) DMSO following a stepwise protocol: 30 mins at $4^{\circ} \mathrm{C}, 2$ hours at $-20^{\circ} \mathrm{C}, 24$ hours at $-80^{\circ} \mathrm{C}$ and stored in liquid nitrogen. After fast thawing, only albumin secretion was determined, and there were no differences between the non-cryopreserved and cryopreserved microencapsulated hepatocytes. Next, the slow freezing cryopreservation of microencapsulated hepatocytes was studied in vivo. Before starting the xenotransplantation studies, Mai et al. investigated the cryopreservation influence on primary rat and immortalized human microencapsulated hepatocytes [122]. In this case, the cryopreservation protocol was performed with a CRF and sample temperature was measured: $12 \mathrm{~min}$ hold at $4^{\circ} \mathrm{C}, 4.2^{\circ} \mathrm{C} / \mathrm{min}$ to $-8^{\circ} \mathrm{C}, 18 \mathrm{~min}$ hold, $4.2^{\circ} \mathrm{C} / \mathrm{min}$ to $-100^{\circ} \mathrm{C}$ and stored in liquid nitrogen. After fast thawing in a $37^{\circ} \mathrm{C}$ water bath, both microencapsulated and cryopreserved cell types showed similar albumin secretion profiles over 7 days compared to the non-cryopreserved group. In the 
xenotransplantation study, the cryopreserved microencapsulated rat or immortalized human hepatocytes showed similar survival rates in mice with induced FLF compared with non-cryopreserved microencapsulated hepatocytes ( $\sim 70 \%$ and $\sim 50 \%$ respectively). A similar study using cryopreserved microencapsulated porcine hepatocytes in FLF induced mice was also performed [123]. Biological functions were determined in vitro in terms of urea and albumin synthesis, and lidocaine, ammonium and diazepam metabolism. Similar cell function profiles were displayed between the cryopreserved microencapsulated hepatocytes and non-cryopreserved microencapsulated hepatocytes, without differences in the survival rates of FLF induced mice after xenotransplantation. The authors claimed that the cryopreserved microencapsulated xenogeneic hepatocytes showed life supporting liver-specific metabolic functions in vivo, and suggested that these findings had great potential for clinical use. In the same way, Hang et al. studied the cryopreservation of microencapsulated human hepatocytes, additionally determining their gene and protein expression [124]. In this case, $2 \mathrm{ml}$ cryovials were cooled with a progressive isopropanol freezing container in a $-80^{\circ} \mathrm{C}$ freezer, and stored in liquid nitrogen. After sample fast thawing, it was demonstrated that the urea and albumin secretion, and gene expression of the hepatocytes were maintained compared with noncryopreserved group. In contrast, the cytochrome P450 (CYP3A4) expression was incremented in the cryopreserved microencapsulated hepatocytes compared to the cryopreserved free hepatocytes. Recently, Jitraruch et al. tested the effect of commercial modified CPA solutions on the cryopreserved microencapsulated rat and human hepatocytes [81]. Viaspan ${ }^{\circledR}$ (with glucose and DMSO 10\% (v/v)) and the Cryostor® solution were compared in terms of metabolic activity, urea synthesis, albumin production and cytochrome P450 activity for the cryopreservation of microencapsulated hepatocytes. Slow freezing was performed stepwise with a CRF, and after fast sample thawing, the modified Viaspan® had the best protective effect in the cryopreservation of microencapsulated rat and human hepatocytes, maintaining cell function for 7 days. Also, it was determined that the addition of an antiapoptotic factor, the benzyloxycarbonyl-Val-Ala-DL-Asp-fluoromethylketone (ZVAD), has a positive effect on cell function of cryopreserved microencapsulated rat hepatocytes, especially in reducing apoptosis. This is the first study using an antiapoptotic factor in the CPA solution for the cryopreservation of microencapsulated hepatocytes, opening another research line for improving the post-thaw cell function. 
The Liver Group, from University College of London (UCL), is developing a bioartificial liver $\left(7 \times 10^{10}\right.$ cells biomass) for the treatment of FLF $[83,88,125]$, studying for that aim, the slow freezing cryopreservation of alginate microencapsulated liver HepG2 spheroids $[12,63,64,74,79,126,127]$. To reduce contamination risks in the process, they compared a CRF without the use of liquid coolants with another CRF that use liquid nitrogen for slow cooling cryopreservation [126]. The $1.25 \mathrm{ml}$ sample cooling was performed with a multi-step protocol and stored in the vapor phase of liquid nitrogen. After fast thawing, both groups were compared for 3 days to noncryopreserved groups in terms of viability, cell counts and albumin secretion. Cell function decreased similarly in both cryopreserved groups at day 3 (90\% for viability, $70 \%$ for cell count and $65 \%$ for albumin secretion), certifying the use of a CRF that enables to work without nitrogen infection risk. Some studies have demonstrated that the active control of ice nucleation temperature could increase the cell recovery after thawing [51,52]. In this regard, the addition of cholesterol, as an ice nucleating agent, in the CPA solution was studied [64]. The cholesterol reduced supercooling and latent cryoinjury during cryopreservation, and consequently almost doubled the cell number after thawing. Moreover, the protein and detoxification function, as well as the oxidative metabolism of cryopreserved microencapsulated liver spheroids were improved when cholesterol was present in the cryopreservation, demonstrating its benefitial effects. Furthermore, the influence of the storage temperature in the microencapsulated liver spheroids was investigated up to a year storing them in a $-80^{\circ} \mathrm{C}$ freezer or in vapor phase nitrogen [74]. The preservation of cell-based products above the Tg was harmful to cell function after thawing. A rapid deterioration in functional recoveries of microencapsulated liver spheroids was displayed after only a few weeks of storage at $-80^{\circ} \mathrm{C}$. However, storage in vapor phase nitrogen maintained the cell function of microencapsulated liver spheroids more than a year. This study demonstrated the importance of banking cell-based products below the $\mathrm{Tg}$ and ensure their appropriate long-term storage. The cryopreservation protocol developed for small volumes $(0.5 \mathrm{ml})$ was scaled up to larger volumes $(\sim 200 \mathrm{ml})$ in a liquid nitrogen-free CRF [12]. Since the CPA excess will limit the cooling and warming rate, and possibly influence cell recovery, the microencapsulated liver spheroids and CPA ratio in cryovials was studied with the aim of reducing the amount of excess CPA volume during cryopreservation. Removal of the CPA excess had no significant impact on cell function after thawing with the biomass to $\mathrm{CPA}$ ratio $1: 0$. Moreover, fast thawing $\left(37^{\circ} \mathrm{C}\right.$ water bath) was the 
best way to recover the cell-based products. Also, the influence of the following cooling rates was investigated in cell function of cryopreserved microencapsulated liver spheroids in cryovials $(0.5 \mathrm{ml})$ and bags $(200 \mathrm{ml})$ : a linear cooling rate of $1{ }^{\circ} \mathrm{C} / \mathrm{min}$, and two non-linear profiles that produced an average cooling rate of $-1{ }^{\circ} \mathrm{C} / \mathrm{min}$ from $-8^{\circ} \mathrm{C}$ to $-60^{\circ} \mathrm{C}$. The first non-linear cooling profile, which has an extended holding period in the temperature zone following ice nucleation and enables more time to be established for osmotic equilibrium between the cells and the external environment at high subzero temperatures, displayed the best results with highest viable cell numbers and high alpha1-fetoprotein production, either in cryovials or bags 24 hours after thawing.

Interestingly, with the aim of cryopreserving a whole bioartificial liver $(2.3 \mathrm{~L}$ biomass) the process of ice formation and propagation was investigated in the slow freezing cryopreservation [63]. In this scenario, the water-ice phase change can be dominated by the network solidification process, which is typically present in small samples such as cryostraws or cryovials, or progressive solidification, which is more often observed in large volumes or environmental freezing. Thus, even the progressive solidification will be the most probable in larger volumes, its effect compared with network solidification was studied in the post-thaw recovery of microencapsulated liver spheroids in cryovials. Two different heat transfer modules were used in an electrical Stirling CRF to freeze $6 \mathrm{ml}$ cryovials, modifying slightly the CPA solution and changing the cholesterol for another ice nucleating agent (Icestart $®$ ). The freezing protocol consisted on cooling at $-1{ }^{\circ} \mathrm{C} / \mathrm{min}$ to $-80^{\circ} \mathrm{C}$ and storage in a $-80^{\circ} \mathrm{C}$ freezer for 7 days. After fast thawing of samples non-significant differences in viable cell number or function between the two solidification processes was demonstrated. By contrast, the ultrastructural effects of the two processes displayed by electron scanning microscopy, showed different behaviors of ice formation. For that reason, the authors suggested that both ice formation processes should be further investigated, focusing especially on progressive solidification that is unavoidable in large volume cryopreservation. Following this research line, the effects of progressive solidification were investigated in the recovery of microencapsulated liver spheroids in the different regions across the frozen cores of $6 \mathrm{~mL}$ cryovials and a $2 \mathrm{~L}$ cylindrical chamber [127]. It has to be noted that whereas in cryovials only microencapsulated liver spheroids were placed, the $2 \mathrm{~L}$ biomass, within the cylindrical chamber, consisted mainly of non-cellularized alginate microcapsules, in which microencapsulated liver spheroids pouches were placed in 
different areas to study the freezing effect in every region (Figure 9A). The microencapsulated liver spheroids proportion, CPA solution, cooling, storage and thawing protocol used for the cryovials were the same as in the previous study. Even though complex manipulations were performed for the cooling and thawing of the microencapsulated liver spheroids pouches in the $2 \mathrm{~L}$ biomass, a similar cooling and fast thawing profile was achieved to study the progressive ice solidification (Figure 9B). The first solidified microencapsulated livers spheroids in the bottom of cryovials showed significantly higher viable cell number and function compared to last solidified on day 3. By contrast, microencapsulated liver spheroids frozen in the middle of the cryovials displayed higher alpha-fetoprotein production and glucose consumption compared to microencapsulated liver spheroids at the cryovial edges on day 2 . On the other hand, cryopreserved microencapsulated liver spheroids in the $2 \mathrm{~L}$ chamber displayed a different behavior after thawing. In the middle of the biomass, the metabolic activity and viable cell number of microencapsulated liver spheroids were higher immediately after thawing. In summary, spatial considerations of microencapsulated liver spheroids had a great impact on the cell recovery either in cryovials or the $2 \mathrm{~L}$ chamber, and these results demonstrated that spatial considerations are important to consider when large volumes are cryopreserved with progressive solidification. To approach the clinic, the cryopreservation of a whole bioartificial liver $(2.3 \mathrm{~L}$ microencapsulated liver spheroids biomass) was investigated [79]. In this case, the 2.3L biomass was frozen with the same CPA solution and protocol. By contrast, as the fast thawing of a whole 2.3L microencapsulated liver spheroids biomass was difficult to achieve, a stepwise slow thawing consisted on $-80^{\circ} \mathrm{C} 2$ hours, $-30^{\circ} \mathrm{C} 1$ hour, $-10^{\circ} \mathrm{C} 1$ hour and final fast thawing with a saline solution was used successfully (Figure 5). Microencapsulated liver spheroids viable cell number, glucose consumption, lactate production and alpha-fetoprotein production recovered to pre-freeze values by day 3 after thawing, and comparing the 2.3L biomass results to the microencapsulated liver spheroids cryopreserved in cryovials, longer recovery times were needed in the biomass for recovering pre-freeze cell function values. For that reason, even the $2.3 \mathrm{~L}$ biomass was successfully cryopreserved, authors suggested that further improvements in thawing would increase the post-thaw cell function of microencapsulated liver spheroids. 


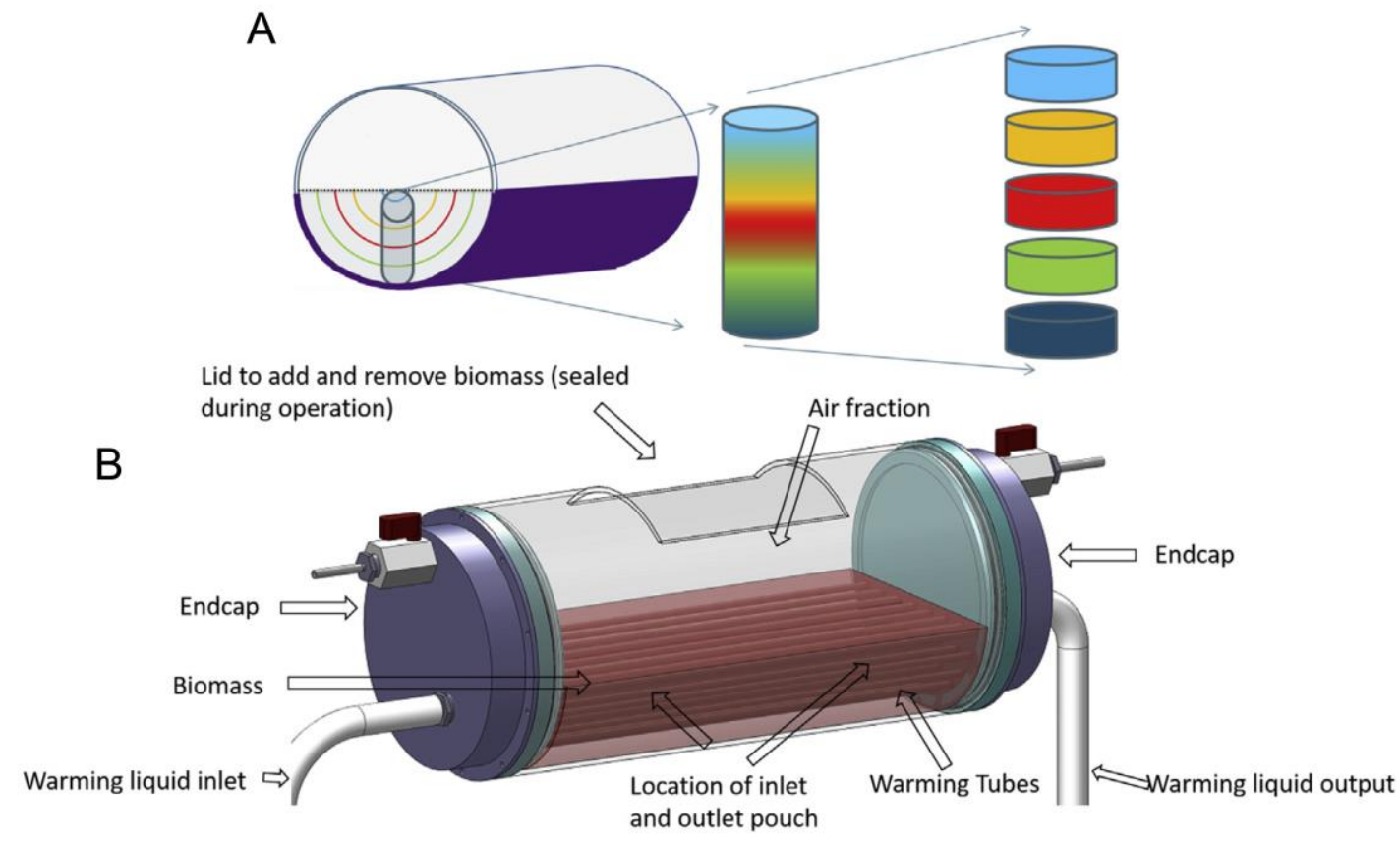

Figure 9: A schematic of the bioartificial liver chamber. The bioartificial liver chamber contained pouches (with microencapsulated liver spheroids) of nylon mesh, permeable to culture medium and ice but impermeable to microencapsulated liver spheroids. This chamber was cooled from the edges (as indicated in purple), and ice developed radially to the central semi-circle, with the semicircles representing areas that solidified at the same time (A). The biomass fill is represented by the dotted black line. This pouch was extracted and dissected into 5 as shown on the right of the figure. These sections were thawed consistently to determine spatial differences in damage on cooling. (B) 25 warming tubes were passed through the biomass (indicated in red), with ethanol equally distributed through each tube using larger endcaps. Pouches were placed within $5 \mathrm{~cm}$ of either the inlet or outlet tubes, with pouches of cells nearer the warming inlet thawing more rapidly. (Figure as originally published in [127])

\subsection{Myoblasts}

Besides the microencapsulated cell types mentioned, others have been cryopreserved for sustained therapeutic molecules delivery [128,129]. Murua et al. investigated various cooling protocols and DMSO concentrations for the cryopreservation of microencapsulated erythropoietin-secreting $\mathrm{C} 2 \mathrm{C} 12$ cells (Table 6)[128]. After fast thawing, the erythropoietin reduction was determined, and the slow cooling protocol showed less erythropoietin reduction compared to non-cryopreserved microencapsulated $\mathrm{C} 2 \mathrm{C} 12$. With this cooling protocol, DMSO concentration was studied $(1,5,10,20$ and 30\% v/v) in CPA solutions. As in other studies, 10\% DMSO 
Table 6: Different encapsulated and cryopreserved cells

\begin{tabular}{|c|c|c|c|c|c|}
\hline $\begin{array}{c}\text { Cell Type } \\
\text { (Biomaterial) }\end{array}$ & $\begin{array}{c}\text { CPA } \\
\text { solution }\end{array}$ & Cryopreservation protocol & $\begin{array}{l}\text { Frozen } \\
\text { volume }\end{array}$ & Main results & Year ${ }^{\text {ref }}$ \\
\hline $\begin{array}{c}\text { Rat PC12 } \\
\text { (Alg-PLL-Alg) }\end{array}$ & $10 \%$ DMSO & $\begin{array}{c}20^{\circ} \mathrm{C} 30 \mathrm{~min} \text {, cooled from }-20^{\circ} \mathrm{C} \text { to }-80^{\circ} \mathrm{C} \text { at a cooling } \\
\text { rate of either } 0.5,1,5,10^{\circ} \mathrm{C} / \mathrm{min} \text {. ST }\end{array}$ & $0.1 \mathrm{ml}$ & $\begin{array}{l}\text { Slow cooling rates of } 0.5 \text { or } 1 \mathrm{C}^{\circ} / \mathrm{min} \text { demonstrated higher viabilities in terms } \\
\text { of dopamine secretion and tryptan blue exclusion assay. }\end{array}$ & $2001^{94}$ \\
\hline $\begin{array}{l}\text { Rat neurospheres } \\
\text { (Alg-PLL-Alg) }\end{array}$ & $\begin{array}{l}\text { Different solutions with } \\
10 \% \text { DMSO }\end{array}$ & $\begin{array}{l}4^{\circ} \mathrm{C} 30 \mathrm{~min} \text {, cooled at }-1 \mathrm{C}^{\circ} / \mathrm{min} \text { to }-80 \mathrm{C}^{\circ} \text { and stored } \mathrm{VN} \text {. } \\
\text { FT }\end{array}$ & $1 \mathrm{ml}$ & $\begin{array}{l}\text { Cryopreserved encapsulated neurospheres with Cryostor® displayed better } \\
\text { viabilities and less cell defragmentation than cryopreserved free cells. }\end{array}$ & $2010^{96}$ \\
\hline $\begin{array}{l}\text { Murine C2C12 } \\
\text { (Alg-PLL-alg) }\end{array}$ & Different $\%$ of DMSO & $\begin{array}{l}\text { Slow cooling: }-20^{\circ} \mathrm{C} 1 \text { hour, transferred into a }-80^{\circ} \mathrm{C} \\
\text { freezer } 23 \text { hours and stored } \mathrm{LN} \text {; slow cooling }+ \text { shaking: } \\
20 \text { min shaking with CPA solution and previous cooling } \\
\text { protocol applied; super cooling: }-80^{\circ} \mathrm{C} 2 \text { hours and stored } \\
\text { LN; maxi-cooling: directly immersed in liquid nitrogen. } \\
\text { FT }\end{array}$ & $2 \mathrm{ml}$ & $\begin{array}{l}\text { Slow cooling demonstrated best results and 10\% DMSO was the best CPA } \\
\text { solution. }\end{array}$ & $2009^{129}$ \\
\hline $\begin{array}{l}\text { Murine } \mathrm{C} 2 \mathrm{C} 12 \\
\quad \text { (Alg) }\end{array}$ & $10 \%$ DMSO & $\begin{array}{l}\quad 4^{\circ} \mathrm{C} 10 \mathrm{~min} \text {, cooling at }-1^{\circ} \mathrm{C} / \mathrm{min} \text { with a Mr. Frosty } \\
\text { freezing container, }-80^{\circ} \mathrm{C} \text { overnight and stored in LN. FT }\end{array}$ & $2 \mathrm{ml}$ & $\begin{array}{l}\text { Slow-cooled samples displayed slightly better outcome regarding metabolic } \\
\text { activity, viability, and insulin secretion compared to the vitrified ones. }\end{array}$ & $2013^{128}$ \\
\hline
\end{tabular}
(Alg) freezing container, $-80^{\circ} \mathrm{C}$ overnight and stored in LN. FT activity, viability, and insulin secretion compared to the vitrified ones.

thawing; DMSO: dimethylsulfoxide; FBS: fetal bovine serum; FCS: fetal calf serum; 
appeared to be optimal in terms of erythropoietin secretion after thawing. Moreover, cryopreserved microencapsulated cells with $10 \%$ DMSO were able to maintain erythropoietin increase in transplanted mice compared to non-cryopreserved microencapsulated cells. Another group also investigated the cryopreservation of microencapsulated genetically modified $\mathrm{C} 2 \mathrm{C} 12$ myoblasts to secrete insulin comparing slow cooling to vitrification [129]. In the slow cooling, insulin-secreting microencapsulated $\mathrm{C} 2 \mathrm{C} 12$ were cooled with $10 \%$ (v/v) DMSO at $-1^{\circ} \mathrm{C} / \mathrm{min}$ in a $\mathrm{Mr}$. Frosty Freezing container to $-80^{\circ} \mathrm{C}$, and stored in liquid nitrogen. After fast thawing, the slow-cooled samples indicated slightly better outcome regarding metabolic activity, viability, and insulin secretion compared to those that had been vitrified. Due to the procedure simplicity authors concluded that slow freezing was superior to vitrification for the cryopreservation of microencapsulated insulin-secreting $\mathrm{C} 2 \mathrm{C} 12$. As in other cell types, it seems that the 10\% DMSO is the best CPA solution for the cryopreservation of microencapsulated $\mathrm{C} 2 \mathrm{C} 12$ cells.

\section{Expert opinion and future directions}

Cell microencapsulation represents a promising technology for the treatment of different diseases; however, it needs further improvements to optimize this cell-based therapy and reach the clinics. In this sense, the cell-based product banking is one of the processes that will help achieving the desired goal, and many works have been performed in the cryopreservation of microencapsulated cells in the last two decades, illustrating different protocols and results. In this regard, there are several aspects in cryopreservation that still have to be optimized to improve cell outcome and capsule integrity, to guarantee the reproducibility and quality of the cell-based products.

Even though DMSO replacement in CPA solution has been a subject of research for the last two decades, DMSO removal seems improbable in this field so far. Every study performed in the slow freezing cryopreservation of microencapsulated cells used DMSO with good results $[12,14,79,96]$. For that reason, another aspect should be also investigated in the slow freezing of microencapsulated cells, such as the appropriate DMSO removal after thawing [27]. In this respect, different methods have been developed to remove CPAs from the cell-based products (e.g, dilution-centrifugation, mass trasnsfer in microfluidical devices or dilution-filtration with hollow fibers), being dilution-centrifugation the most widely used method [130]. In the reviewed studies, no 
one determined if the applied post-thaw recovery method gets rid of the DMSO completely from microcapsules. Although, they are not normally employed or added in cryopreservation studies, with the aim of measuring the residual CPA after thawing, capillary zone electrophoresis [131], high-performance liquid chromatography (HPLC) [132], gas chromatography [133] or electrical conductivity [130] methods have been proposed. These techniques, determing DMSO removal, would be very useful, especially when the cell-based products are implanted in patients. In this way, the DMSO adverse effects will not take down the future use of these microencapsulated cells in the clinic. The ice-nucleating agent addition in CPA solution raised the ice nucleation temperature in cooling and demonstrated its benefits in the post-thaw microencapsulated liver spheroids cell function [64]. However, the ice nucleation temperature increment could also impair capsules (Figure 8B)[116]. In this respect, it has to be taken into account that capsules damage could alter the biomechanical properties, changing their behavior (e.g., as sustained drug delivery or cell delivery system) and affect the quality of the cell-based products. In this sense, light microscopy observation has been widely performed to determine general microcapsules appearance in terms of circularity and broken capsules after thawing [116,128]. Those observations are insufficient to determine capsule stiffness and pore size, and assure the capsules mechanical stability. For that reason, even ice-nucleating agents should be used to improve cell function, the capsules mechanical integrity should also be investigated with other assays (e.g., capsule swelling [14]) after their cryopreservation. In any case, the capsules biomechanical properties is a key aspect that must always be studied to guarantee the post-thaw quality of the cell-based products. Lastly, different additives have been included in CPA solution to reduce cell apoptosis and death by other mechanisms after cryopreservation. Often cells look healthy and viable immediately after thawing, but after some hours a significant portion of cells are lost due to the overall mechanisms involved in cell apoptosis and necrosis after cryopreservation, the called cryopreservation induced onset cell death (CIOCD)[134]. Mainly this phenomena occurs when cryopreservation processes may be optimized to protect cells structurally, but fails to adequately manage the other stresses associated with this process (e.g., reactive oxygen species creation). With the scope of reducing the CIOCD phenomena, antioxidants and anti-apoptotic factors were included in CPA solutions for the cryopreservation of microencapsulated cells. On the one hand, the antioxidants (trolox and catalase) were used in the cryopreservation of microencapsulated liver spheroids, 
but as their effect was not compared to cryopreserved microencapsulated liver spheroids without the antioxidants, their efficiency could be questioned [12]. On the other hand, anti-apoptotic factor effects in CPA solution were investigated with hepatocytes reducing apoptosis significantly in the first 24 hours after thawing [81]. In this regard, cell death and apoptosis behavior within microcapsules have not been carefully studied after cryopreservation. However, the post-thaw cell loss profile was determined in highly dense microencapsulated liver spheroids [12,64,79,127]. Cell death and proliferation mechanisms were balanced towards cell death in the first two days, displaying up to $40 \%$ fewer cells compared to pre-freezing cell numbers. After the second day, when apoptosis and cell death diminished, microencapsulated liver spheroids behavior changed increasing the viable cell number and recovering prefreezing cell functions. The displayed microencapsulated liver spheroids cell loss behavior makes sense due to CIOCD phenomena that are normally observed within 6 to $48 \mathrm{~h}$ after post-thaw culture $[134,135]$. Any improvement made by the antioxidants or anti-apoptotic factors in microencapsulated liver spheroids cell function recovery time will enable significant progress in the development of the bioartificial liver for the clinic. For that reason, even though there are few studies performed with these molecules, the antioxidants and anti-apoptotic factor addition could inhibit the CIOCD phenomena and improve overall cryopreservation efficiency in microencapsulated cells.

CPA addition and removal have also changed over the last two decades. In the first studies, the CPA solutions were not added chilled without avoiding the CPA related cytotoxicity $[94,95,108,121]$, but rapidly protocols changed and CPA solutions were added chilled to samples $[123,128]$. In the same way, samples were not cooled before cooling, but nowadays all microencapsulated cells are chilled adding a holding step at $4^{\circ} \mathrm{C}$ prior to freezing $[64,126]$. Moreover, CPA removal after sample recovery has not been described; it has usually been performed by the slow drop by drop dilution of the microencapsulated cells in the CPA solution. Although this method works for the thawing of microencapsulated cells, more complex investigations of CPA dilution after thawing should be investigated to improve cell function and diminish the CIOCD phenomena. In this regard, slow freezing could take advantage of vitrification, in which the thawing protocols have been deeply investigated to upgrade the thawing process [54]. Moving forward, cooling has been described extensively in the reviewed studies, showing that diverse protocols were used independently of the cell type. In this sense, cooling protocols (e.g., non-linear or linear, with induced ice nucleation) have been 
investigated commonly with a CRF to reduce the IIF and optimize post-thaw cell outcome. They have changed from non-linear to linear profiles due to their simplicity and high-quality results obtained either with small or large volumes [12]. Although CRF enables the optimization of the cooling process preventing sub-optimal cell functions and CIOCD phenomena after thawing [94], passive progressive freezing containers were also used for the cryopreservation of different microencapsulated cells, displaying good results $[14,117,128]$. In any case, if something has been common in all the described studies is that microencapsulated cells were cooled until the range of -80 to $100^{\circ} \mathrm{C}$ and then immersed in liquid or vapor phase nitrogen to store the cell-based products below the $\mathrm{Tg}$ temperature. It has to be noted that few studies measured or displayed the temperature profiles in the freeze-thaw process. Importantly, the temperature measurement during cryopreservation would probably explain the difference obtained between some of the reviewed studies, as ice nucleation temperature and the real cooling profile would be showed giving more information to the field. We believe that this is one of the aspects that being applied will significantly improve the overall clarity and understanding of the studies. Lastly, for the thawing of microencapsulated cells, the fast thawing procedure have been extensively used by sample immersion in a water bath at $37^{\circ} \mathrm{C}$. Slow thawing was studied when the large samples size made impossible the fast thawing. In this sense, a 2.3L microencapsulated liver spheroids biomass, which works as a bioartificial liver, was thawed in a stepwise manner [79]. Even though good results were obtained with functional recovery of the biomass at 72hours, further improvements in slow thawing would reduce the post-thaw recovery time of the bioartificial liver. In this regard, among the reviewed studies, the bioartificial liver is the only microencapsulated cell-based product that seems to have the potential to reach the clinic. However, the bioartificial liver biomass has to be manufactured under GMPs in all process, assuring the reproducibility and quality of the biosystem to reach the clinics [136]. On this regard, taken into considreation the quality controls that are used on the handling, processing and disposal of stem cells, which are the most used cryopreserved cell therapies around the world [137], we have enumerated the aspects that should be followed on the quality control of the microencapsulated cells from the elaboration to the use in clinics (Figure 10). First, the function of the encapsulated cells (cell viability, menbrane integrity, metabolic activity and therapuetic molecule release quantification among others) as well as the integrity of the microcapsules (swelling assay) should be assesed always before cryopreservation, being 
mandatory the microcapsules integrity assesment when the goal is the implantation. Next, during the freeze-thaw process the temperature must be tracked to ensure no thermal flucutations that could affect product stability. Finally, after thawing the following two main aspects should be considered: the microencapsulated cell function and microcapsules integrity maintainance should be assesed, and residual CPA after removal should be quantified with the aformentioned analytical techniques to prevent CPA related toxicity. In addition, clinicians training with microencapsulated cells result an important factor to avoid handling errors that can take down the effectiveness of the cell therapy product. Considering all these quality control steps, currently a clinical scale bioartificial liver has been developed for GMP [83], showing its potential in vivo and demonstrating that a big part of the path has been done for the treatment of FLF patients.

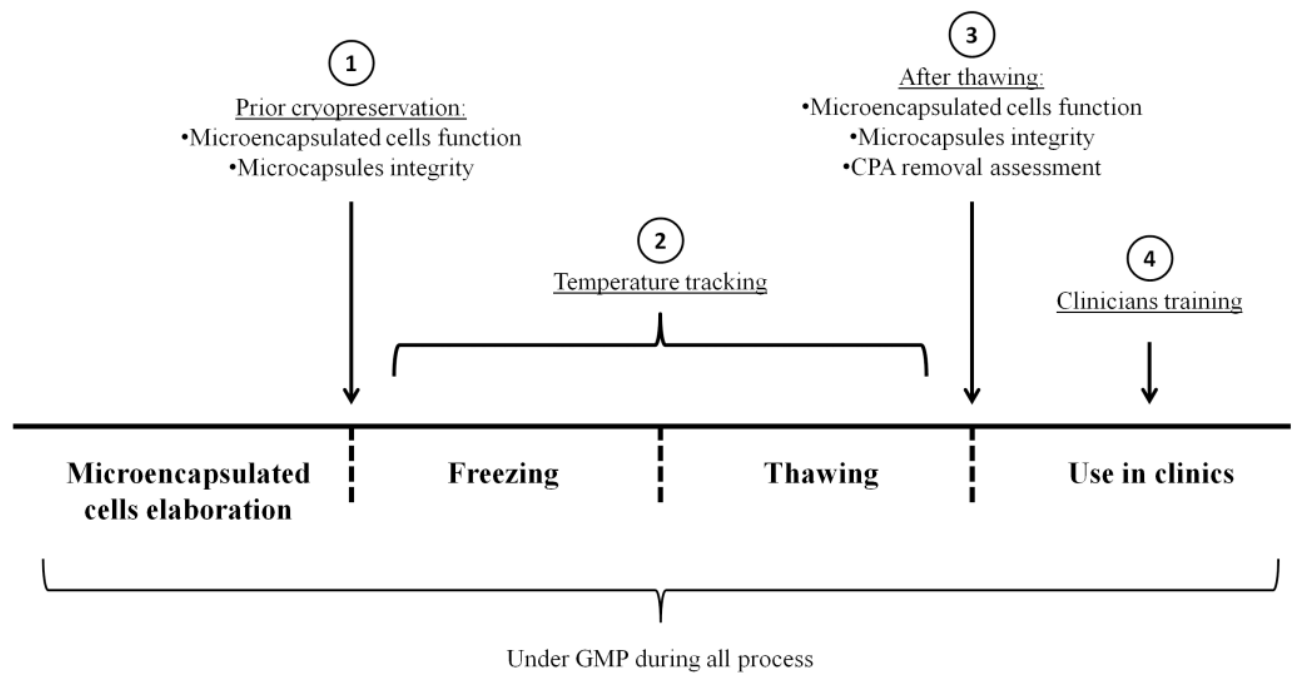

Figure 10: Quality control steps of microencapsulated cells from elaboration to clinics: 1) Assessment of microencapsulated cell function and microcapsules integrity (mandatory for implantation purposes before cryopreservation) 2) Temperature tracking during freeze-thaw process; 3) Quantification of microencapsulated cells function and microcapsules integrity maintenance after thawing, and determination of residual CPA after complete removal. 4) Specific clinicians training with microencapsulated cells handling. All the steps should follow GMP procedures. 


\section{Conclusions}

Slow freezing cryopreservation has been widely studied and developed over recent years for the preservation of many cells, tissues or cell-based products. In this sense, microencapsulated cells are one of the biosystems that has been extensively studied to be cryopreserved with the aim of providing a cell-based product bank that facilitates the "on demand" access of patients to the treatments in a clinic far from the manufacturer. Although many studies have been performed with microencapsulated cells displaying successful results, there are many aspects in the slow freezing procedure that should be optimized, such as the CPA solution and the freeze-thaw process. Thus, further research of the slow freezing in these cell-based products is needed for this technology to the reach the desired goal, the clinical translation. 


\section{Acknowledgments}

Author thanks the University of the Basque Country (UPV/EHU) and the CIBER in Bioengineering, Biomaterials \& Nanomedicine (CIBER-BBN) for granted fellowship, and the research association period secondment at the Liver Group of the University College of London (UCL). Authors also wish to thank the intellectual and technical assistance from the ICTS "NANBIOSIS", more specifically by the Drug Formulation Unit (U10) of the CIBER-BBN at the UPV/EHU.

\section{Declaration of interest}

The authors have no relevant affiliations or financial involvement with any organization or entity with a financial interest in or financial conflict with the subject matter or materials discussed in the manuscript. This includes employment, consultancies, honoraria, stock ownership or options, expert testimony, grants or patents received or pending, or royalties. 


\section{Figures:}

Figure 1: Schematic of Mazur's 2-factor hypothesis. A cell with CPA protection subjected to cooling at different rates. Maximum functional recovery is achieved with an optimal cooling rate providing reversible dehydration occurring over the high subzero temperature range. If cooling is too slow, irreversible injurious dehydration can take place, for example the mitochondria and endoplasmic reticulum are structurally compromised. If cooling is too fast, cells do not have time to optimally dehydrate, and residual intracellular water can form ice, which is again injurious and can compromise structure of organelles. For many nucleated mammalian cells, 'optimal' cooling equates to rates of around $-1^{\circ} \mathrm{C} \mathrm{min}^{-1}$. Copyright of BioInsights Publishing Ltd. Cell Gene Therapy Insights 2017; 3(5), 359-378. DOI: 10.18609/cgti.2017.038.

Figure 2: Schematic process of slow cooling cryopreservation. Cells are usually chilled to avoid the cytotoxic effect of CPAs, and at $\sim 4^{\circ} \mathrm{C}$ the cooled CPA solution is added, enabling CPAs to permeate the cells during a holding time. Then samples are cooled slowly, and usually around $-7^{\circ} \mathrm{C}$ ice nucleation occurs. That could be induced by active nucleation or modulated by adding an ice nucleating agent to the CPA solution. Samples continue cooling until $-80^{\circ} \mathrm{C}$, where samples are cooled below the glass transition temperature by nitrogen liquid immersion, approx. $-160^{\circ} \mathrm{C}$, and held in the cryogenic state. The cryopreserved samples will form a solidified mixed matrix of ice, CPAs, solute and a biomass, composed of extremely dehydrated cells that contain no ice. When is required, samples could be thawed quickly, and after CPA removal at $4^{\circ} \mathrm{C}$ the sample would be ready to use.

Figure 3: Ice nucleation affects on the recovery of microencapsulated cells. A) Evaluation of membrane integrity and efficiency of re-cultivation after cryomicroscopy on primate MSCs. B) Microencapsulated cell spheroids viability when cooled under different cooling protocols showing that regardless the used protocol, higher ice nucleation results in higher viabilities. C) Cryoscanning electron microscopy of fractured cryovials after cooling at a linear rate of $-1{ }^{\circ} \mathrm{C} / \mathrm{min}$. Ultrastructure resulting from controlled ice nucleation $(\mathrm{A}, \mathrm{C})$ is compared to spontaneous ice nucleation $(2,4)$. 
In figure (B) sectioned alginate beads that are $\sim 500 \mu \mathrm{m}$ in diameter are outlined. In (1, 3, 4), cell clusters (c), ice voids (i), and smooth freeze concentrated alginate and cryoprotectant (CPA) (*) have been labeled. Scale bars on $(1,2) 200 \mathrm{~mm}$, and on $(3,4)$ 20 mm. Notes: Spon: spontaneous $* \mathrm{p}<0.05$; ** $\mathrm{p}<0.01$. $(\mathrm{n}=3)$. A) Reprinted from Active control of the nucleation temperature enhances freezing survival of multipotent mesenchymal stromal cells, 71(3), Lauterboeck L, Hofmann N, Mueller T, Glasmacher B, Cryobiology , 384-90, Copyright (2018), with permission from Elsevier. (B and C as originally published in [12])

Figure 4: Differences in cooling profiles of cryovials and a $2 \mathrm{~L}$ chamber. Temperature profiles in both aluminum (A) and acetal (B) heat transfer modules measured on the EF600-103 Stirling cryocooler-based controlled rate freezer. C) Measured temperature profiles inside the bioartificial liver chamber during cooling of a thermal mimic with $10 \%$ glycerol solution. (Figure as originally published in [63])

\section{Figure 5: Warming profiles experienced during warming of the large volume} cryopreservation cylindrical chamber. Thermocouples were placed at the bottom of the biomass (black) and the top of the biomass (lightest grey), as well as three others equidistant apart between the bottom and top following a straight line through the deepest part of the sample (dark to lighter grey). Section A demarks warming in the $80^{\circ} \mathrm{C}$ freezer, section $\mathrm{B}$ thawing in the $-30^{\circ} \mathrm{C}$ freezer, and section $\mathrm{C}-10^{\circ} \mathrm{C}$ in the Planer controlled rate freezer. (Figure as originally published in [79])

Figure 6: Scheme of the microencapsulation process. Cells are suspended in ultrapure alginate $(1-3 \%(\mathrm{w} / \mathrm{v}))$ obtaining a viscous solution with variable cell densities depending on cell type and therapeutic application $\left(1-5 \times 10^{6}\right.$ cells $/ \mathrm{mL}$ alginate). This cell suspension is next extruded through a needle in which suspensions droplets can be generated by different encapsulation technologies (electrostatic, air or jet cutter) which are solidified in a bivalent cations bath, such as calcium chloride. The generated microcapsules can be directly used for therapeutic applications, or coated with polycationic molecules, such as poly-L-lysine. 
Figure 7: Cooling rate effects on cell function after thawing and ice nucleation temperatures. Viability and cooling rate relationship determined by dopamine secretion (A) or trypan blue exclusion assay (B). C) Cryomicroscopy images of microencapsulated P12 cells with slow (a) and fast (b) cooling rates showing differences in ice nucleation temperatures. Scale bar: $200 \mu \mathrm{m}$. Reprinted from Improvement in the Viability of Cryopreserved Cells By Microencapsulation, Matsumoto Y, Morinaga Y, Ujihira M, Oka K, Tanishita K, JSME international Journal Series C, 384-90, Copyright (2018), with permission from JSME.

Figure 8: Evaluation of monkey MSCs microencapsulated in alginate beads. A) Live (green)-dead (red) staining of microencapsulated monkey MSCs after thawing following seven days in culture (day 0 , day 3, day 7) utilizing 5\%, 7.5\% and $10 \%$ (v/v) DMSO with $30 \mathrm{~min}$ and $45 \mathrm{~min}$ of pre-loading interval. Freezing was performed using $2.5 \%, 5 \%, 7.5 \%$ and $10 \%$ (v/v) DMSO with respective pre-freeze loading interval. B) Evaluation of microencapsulated monkey MSCs during freezing/thawing using cryomicroscopy. The temperature value at $\mathrm{T}=\mathrm{TN}$ represents the temperature of ice formation. $T_{\text {DMSO }}$ represents the DMSO pre-loading interval. The structural damage of the alginate beads rises with rising temperatures of ice formation. Stars depict the process settings that noticeably impaired the homogeneity and/or structure of alginate beads. Scale bars represent $250 \mu \mathrm{m}$. Scale bar: $200 \mu \mathrm{m}$. Reprinted from Multipotent stromal cells derived from common marmoset Callithrix jacchus within alginate 3D environment: Effect of cryopreservation procedures, 71, O. Gryshkov, N. Hofmann, L. Lauterboeck, D. Pogozhykh, T. Mueller, B. Glasmacher, Cryobiology, 103-111, Copyright (2018), with permission from Elsevier.

Figure 9: A schematic of the bioartificial liver chamber. The bioartificial liver chamber contained pouches (with microencapsulated liver spheroids) of nylon mesh, permeable to culture medium and ice but impermeable to microencapsulated liver spheroids. This chamber was cooled from the edges (as indicated in purple), and ice developed radially to the central semi-circle, with the semicircles representing areas that solidified at the same time (A). The biomass fill is represented by the dotted black line. This pouch was extracted and dissected into 5 as shown on the right of the figure. These sections were thawed consistently to determine spatial differences in damage on 
cooling. (B) 25 warming tubes were passed through the biomass (indicated in red), with ethanol equally distributed through each tube using larger endcaps. Pouches were placed within $5 \mathrm{~cm}$ of either the inlet or outlet tubes, with pouches of cells nearer the warming inlet thawing more rapidly. (Figure as originally published in [127])

Figure 10: Quality control steps of microencapsulated cells from elaboration to clinics: 1) Assessment of microencapsulated cell function and microcapsules integrity (mandatory for implantation purposes before cryopreservation) 2) Temperature tracking during freeze-thaw process; 3) Quantification of microencapsulated cells function and microcapsules integrity maintenance after thawing, and determination of residual CPA after complete removal. 4) Specific clinicians training with microencapsulated cells handling. All the steps should follow GMP procedures. 


\section{Bibliography}

\section{Reference List}

[1] J.M. Baust, W.L. Corwin, R. VanBuskirk, J.G. Baust, Biobanking: The Future of Cell Preservation Strategies, Adv. Exp. Med. Biol. 864 (2015) 37-53.

[2] E.J. Woods, S. Thirumala, S.S. Badhe-Buchanan, D. Clarke, A.J. Mathew, Off the shelf cellular therapeutics: Factors to consider during cryopreservation and storage of human cells for clinical use, Cytotherapy. 18 (2016) 697-711.

[3] X. Yu, G. Chen, S. Zhang, A model to predict the permeation kinetics of dimethyl sulfoxide in articular cartilage, Biopreserv Biobank. 11 (2013) 51-56.

[4] L.L. Kuleshova, S.S. Gouk, D.W. Hutmacher, Vitrification as a prospect for cryopreservation of tissue-engineered constructs, Biomaterials. 28 (2007) 1585-1596.

[5] G. Vajta, L. Rienzi, F.M. Ubaldi, Open versus closed systems for vitrification of human oocytes and embryos, Reprod. Biomed. Online. 30 (2015) 325-333.

[6] F. Kutluyer, M. Kayim, F. Ogretmen, S. Buyukleblebici, P.B. Tuncer, Cryopreservation of rainbow trout Oncorhynchus mykiss spermatozoa: effects of extender supplemented with different antioxidants on sperm motility, velocity and fertility, Cryobiology. 69 (2014) 462-466.

[7] G.M. Fahy, B. Wowk, R. Pagotan, A. Chang, J. Phan, B. Thomson, L. Phan, Physical and biological aspects of renal vitrification, Organogenesis. 5 (2009) 167-175.

[8] A. Bissoyi, K. Pramanik, N.N. Panda, S.K. Sarangi, Cryopreservation of hMSCs seeded silk nanofibers based tissue engineered constructs, Cryobiology. 68 (2014) 332342.

[9] E. Fernandez Gallardo, C. Spiessens, T. D'Hooghe, S. Debrock, Effect of day 3 embryo morphometrics and morphokinetics on survival and implantation after slow freezing-thawing and after vitrification-warming: a retrospective cohort study, Reprod. Biol. Endocrinol. 15 (2017) 79-017-0299-5.

[10] J.W. Lagerberg, Cryopreservation of red blood cells, Methods Mol. Biol. 1257 (2015) 353-367.

[11] C.Y. Fong, A. Subramanian, A. Biswas, A. Bongso, Freezing of Fresh Wharton's Jelly From Human Umbilical Cords Yields High Post-Thaw Mesenchymal Stem Cell Numbers for Cell-Based Therapies, J. Cell. Biochem. 117 (2016) 815-827.

[12] I. Massie, C. Selden, H. Hodgson, B. Fuller, S. Gibbons, G.J. Morris, GMP cryopreservation of large volumes of cells for regenerative medicine: active control of the freezing process, Tissue Eng. Part C. Methods. 20 (2014) 693-702.

[13] A.I. Pravdyuk, Y.A. Petrenko, B.J. Fuller, A.Y. Petrenko, Cryopreservation of alginate encapsulated mesenchymal stromal cells, Cryobiology. 66 (2013) 215-222. 
[14] H. Gurruchaga, J. Ciriza, L. Saenz Del Burgo, J.R. Rodriguez-Madoz, E. Santos, F. Prosper, R.M. Hernandez, G. Orive, J.L. Pedraz, Cryopreservation of microencapsulated murine mesenchymal stem cells genetically engineered to secrete erythropoietin, Int. J. Pharm. 485 (2015) 15-24.

[15] N. Cagol, W. Bonani, D. Maniglio, C. Migliaresi, A. Motta, Effect of cryopreservation on cell-laden hydrogels: comparison of different cryoprotectants, Tissue Eng. Part C. Methods. (2017).

[16] G.D. Elliott, S. Wang, B.J. Fuller, Cryoprotectants: A review of the actions and applications of cryoprotective solutes that modulate cell recovery from ultra-low temperatures, Cryobiology. 76 (2017) 74-91.

[17] B.J. Fuller, Cryoprotectants: the essential antifreezes to protect life in the frozen state, Cryo Letters. 25 (2004) 375-388.

[18] S.P. Leibo, J.J. McGrath, E.G. Cravalho, Microscopic observation of intracellular ice formation in unfertilized mouse ova as a function of cooling rate, Cryobiology. 15 (1978) 257-271.

[19] H.T. Meryman, Cryopreservation of living cells: principles and practice, Transfusion. 47 (2007) 935-945.

[20] D.Y. Gao, J. Liu, C. Liu, L.E. McGann, P.F. Watson, F.W. Kleinhans, P. Mazur, E.S. Critser, J.K. Critser, Prevention of osmotic injury to human spermatozoa during addition and removal of glycerol, Hum. Reprod. 10 (1995) 1109-1122.

[21] P. Mazur, Principles of Cryobiology, in: B. Fuller, N. Lane, E.E. Benson (Eds.), Life in the Frozen State, CRC press, 2004, pp. 3-65.

[22] B. Fuller, J. Gonzalez-Molina, E. Erro, J. De Mendonca, S. Chalmers, M. Awan, A. Poirier, C. Selden, Applications and optimization of cryopreservation technologies to cellular therapeutics, Cell Gene Therapy Insights. 3 (2017) 359-378.

[23] B.P. Best, Cryoprotectant Toxicity: Facts, Issues, and Questions, Rejuvenation Res. 18 (2015) 422-436.

[24] S. Mantri, S. Kanungo, P.C. Mohapatra, Cryoprotective Effect of Disaccharides on Cord Blood Stem Cells with Minimal Use of DMSO, Indian. J. Hematol. Blood Transfus. 31 (2015) 206-212.

[25] S.B. Shivakumar, D. Bharti, R.B. Subbarao, S.J. Jang, J.S. Park, I. Ullah, J.K. Park, J.H. Byun, B.W. Park, G.J. Rho, DMSO- and Serum-Free Cryopreservation of Wharton's Jelly Tissue Isolated From Human Umbilical Cord, J. Cell. Biochem. 117 (2016) 2397-2412.

[26] P. Halle, O. Tournilhac, W. Knopinska-Posluszny, J. Kanold, P. Gembara, N. Boiret, C. Rapatel, M. Berger, P. Travade, S. Angielski, J. Bonhomme, F. Demeocq, Uncontrolled-rate freezing and storage at -80 degrees $\mathrm{C}$, with only 3.5-percent DMSO 
in cryoprotective solution for 109 autologous peripheral blood progenitor cell transplantations, Transfusion. 41 (2001) 667-673.

[27] Z. Shu, S. Heimfeld, D. Gao, Hematopoietic SCT with cryopreserved grafts: adverse reactions after transplantation and cryoprotectant removal before infusion, Bone Marrow Transplant. 49 (2014) 469-476.

[28] G.N. Stacey, C.J. Connon, K. Coopman, A.J. Dickson, B. Fuller, C.J. Hunt, P. Kemp, J. Kerby, J. Man, P. Matejtschuk, H. Moore, J. Morris, R.O. Oreffo, N. Slater, S. Ward, C. Wiggins, H. Zimmermann, Preservation and stability of cell therapy products: recommendations from an expert workshop, Regen. Med. 12 (2017) 553-564.

[29] S. Roy, S. Arora, P. Kumari, M. Ta, A simple and serum-free protocol for cryopreservation of human umbilical cord as source of Wharton's jelly mesenchymal stem cells, Cryobiology. 68 (2014) 467-472.

[30] O. Rogulska, Y. Petrenko, A. Petrenko, DMSO-free cryopreservation of adiposederived mesenchymal stromal cells: expansion medium affects post-thaw survival, Cytotechnology. 69 (2017) 265-276.

[31] M. Zhang, H. Oldenhof, H. Sieme, W.F. Wolkers, Freezing-induced uptake of trehalose into mammalian cells facilitates cryopreservation, Biochim. Biophys. Acta. 1858 (2016) 1400-1409.

[32] M. Zhang, H. Oldenhof, H. Sieme, W.F. Wolkers, Combining endocytic and freezing-induced trehalose uptake for cryopreservation of mammalian cells, Biotechnol. Prog. 33 (2017) 229-235.

[33] F. Tramer, F. Rocco, F. Micali, G. Sandri, E. Panfili, Antioxidant systems in rat epididymal spermatozoa, Biol. Reprod. 59 (1998) 753-758.

[34] S.C. Sikka, Role of oxidative stress and antioxidants in andrology and assisted reproductive technology, J. Androl. 25 (2004) 5-18.

[35] L.S. Limaye, Bone marrow cryopreservation: improved recovery due to bioantioxidant additives in the freezing solution, Stem Cells. 15 (1997) 353-358.

[36] L.S. Limaye, V.P. Kale, Cryopreservation of human hematopoietic cells with membrane stabilizers and bioantioxidants as additives in the conventional freezing medium, J. Hematother. Stem Cell Res. 10 (2001) 709-718.

[37] L.M. Sasnoor, V.P. Kale, L.S. Limaye, Prevention of apoptosis as a possible mechanism behind improved cryoprotection of hematopoietic cells by catalase and trehalose, Transplantation. 80 (2005) 1251-1260.

[38] J.P. Motta, B.E. Gomes, L.F. Bouzas, F.H. Paraguassu-Braga, L.C. Porto, Evaluations of bioantioxidants in cryopreservation of umbilical cord blood using natural cryoprotectants and low concentrations of dimethylsulfoxide, Cryobiology. 60 (2010) 301-307. 
[39] S.K. Kim, H.W. Youm, J.R. Lee, C.S. Suh, Chapter 4 Role of Antioxidants and Antifreeze Proteins in Cryopreservation/Vitrification, Methods Mol. Biol. 1568 (2017) 45-63.

[40] J.F. Carpenter, T.N. Hansen, Antifreeze protein modulates cell survival during cryopreservation: mediation through influence on ice crystal growth, Proc. Natl. Acad. Sci. U. S. A. 89 (1992) 8953-8957.

[41] S. Matsumoto, M. Matsusita, T. Morita, H. Kamachi, S. Tsukiyama, Y. Furukawa, S. Koshida, Y. Tachibana, S. Nishimura, S. Todo, Effects of synthetic antifreeze glycoprotein analogue on islet cell survival and function during cryopreservation, Cryobiology. 52 (2006) 90-98.

[42] S.G. Lee, H.Y. Koh, J.H. Lee, S.H. Kang, H.J. Kim, Cryopreservative effects of the recombinant ice-binding protein from the arctic yeast Leucosporidium sp. on red blood cells, Appl. Biochem. Biotechnol. 167 (2012) 824-834.

[43] G. Grilli, A. Porcellini, G. Lucarelli, Role of serum on cryopreservation and subsequent viability of mouse bone marrow hemopoietic stem cells, Cryobiology. 17 (1980) 516-520.

[44] T. Shimazu, Y. Mori, A. Takahashi, H. Tsunoda, A. Tojo, T. Nagamura-Inoue, Serum- and xeno-free cryopreservation of human umbilical cord tissue as mesenchymal stromal cell source, Cytotherapy. 17 (2015) 593-600.

[45] L.B. Williams, C. Co, J.B. Koenig, C. Tse, E. Lindsay, T.G. Koch, Response to Intravenous Allogeneic Equine Cord Blood-Derived Mesenchymal Stromal Cells Administered from Chilled or Frozen State in Serum and Protein-Free Media, Front. Vet. Sci. 3 (2016) 56.

[46] R. Fabbri, G. Pasquinelli, D. Keane, V. Magnani, R. Paradisi, S. Venturoli, Optimization of protocols for human ovarian tissue cryopreservation with sucrose, 1,2propanediol and human serum, Reprod. Biomed. Online. 21 (2010) 819-828.

[47] H. Gurruchaga, L. Saenz Del Burgo, A. Garate, D. Delgado, P. Sanchez, G. Orive, J. Ciriza, M. Sanchez, J.L. Pedraz, Cryopreservation of Human Mesenchymal Stem Cells in an Allogeneic Bioscaffold based on Platelet Rich Plasma and Synovial Fluid, Sci. Rep. 7 (2017) 15733-017-16134-6.

[48] C.B. Ware, A.M. Nelson, C.A. Blau, Controlled-rate freezing of human ES cells, BioTechniques. 38 (2005) 879-80, 882-3.

[49] G.J. Morris, E. Acton, Controlled ice nucleation in cryopreservation--a review, Cryobiology. 66 (2013) 85-92.

[50] M. Akhoondi, H. Oldenhof, C. Stoll, H. Sieme, W.F. Wolkers, Membrane hydraulic permeability changes during cooling of mammalian cells, Biochim. Biophys. Acta. 1808 (2011) 642-648. 
[51] N. Skorobogatova, A.N. Novikov, B.J. Fuller, A.Y. Petrenko, Importance of a three-stage cooling regime and induced ice nucleation during cryopreservation on colony-forming potential and differentiation in mesenchymal stem progenitor cells from human fetal liver, Cryo Letters. 31 (2010) 371-379.

[52] L. Lauterboeck, N. Hofmann, T. Mueller, B. Glasmacher, Active control of the nucleation temperature enhances freezing survival of multipotent mesenchymal stromal cells, Cryobiology. 71 (2015) 384-390.

[53] H.Y. Elmoazzen, J.A. Elliott, L.E. McGann, Osmotic transport across cell membranes in nondilute solutions: a new nondilute solute transport equation, Biophys. J. 96 (2009) 2559-2571.

[54] A. Lawson, I.N. Mukherjee, A. Sambanis, Mathematical modeling of cryoprotectant addition and removal for the cryopreservation of engineered or natural tissues, Cryobiology. 64 (2012) 1-11.

[55] D.K. Gardner, M. Lane, J. Stevens, W.B. Schoolcraft, Changing the start temperature and cooling rate in a slow-freezing protocol increases human blastocyst viability, Fertil. Steril. 79 (2003) 407-410.

[56] Z. Shu, X. Kang, H. Chen, X. Zhou, J. Purtteman, D. Yadock, S. Heimfeld, D. Gao, Development of a reliable low-cost controlled cooling rate instrument for the cryopreservation of hematopoietic stem cells, Cytotherapy. 12 (2010) 161-169.

[57] A. Abazari, J.A. Elliott, L.E. McGann, R.B. Thompson, MR spectroscopy measurement of the diffusion of dimethyl sulfoxide in articular cartilage and comparison to theoretical predictions, Osteoarthritis Cartilage. 20 (2012) 1004-1010.

[58] R. Sharma, G.K. Law, K. Rekieh, A. Abazari, J.A. Elliott, L.E. McGann, N.M. Jomha, A novel method to measure cryoprotectant permeation into intact articular cartilage, Cryobiology. 54 (2007) 196-203.

[59] G.M. Fahy, Analysis of "solution effects" injury: cooling rate dependence of the functional and morphological sequellae of freezing in rabbit renal cortex protected with dimethyl sulfoxide, Cryobiology. 18 (1981) 550-570.

[60] P.Y. Lin, Y.C. Yang, S.H. Hung, S.Y. Lee, M.S. Lee, I.M. Chu, S.M. Hwang, Cryopreservation of human embryonic stem cells by a programmed freezer with an oscillating magnetic field, Cryobiology. 66 (2013) 256-260.

[61] E. Puschmann, C. Selden, S. Butler, B. Fuller, Liquidus tracking: controlled rate vitrification for the cryopreservation of larger volumes and tissues, Cryo Letters. 35 (2014) 345-355.

[62] L.V. Gosden, Techniques for slow cryopreservation of embryos, Methods Mol. Biol. 1154 (2014) 407-438. 
[63] P. Kilbride, G.J. Morris, S. Milne, B. Fuller, J. Skepper, C. Selden, A scale down process for the development of large volume cryopreservation, Cryobiology. 69 (2014) 367-375.

[64] I. Massie, C. Selden, H. Hodgson, B. Fuller, Cryopreservation of encapsulated liver spheroids for a bioartificial liver: reducing latent cryoinjury using an ice nucleating agent, Tissue Eng. Part C. Methods. 17 (2011) 765-774.

[65] D.C. Linch, L.J. Knott, K.G. Patterson, D.A. Cowan, P.G. Harper, Bone marrow processing and cryopreservation, J. Clin. Pathol. 35 (1982) 186-190.

[66] J.L. Rios, Y. Rabin, Thermal expansion of blood vessels in low cryogenic temperatures, Part II: Vitrification with VS55, DP6, and 7.05 M DMSO, Cryobiology. 52 (2006) 284-294.

[67] R. Mitchell, J.E. Wagner, C.G. Brunstein, Q. Cao, D.H. McKenna, T.C. Lund, M.R. Verneris, Impact of long-term cryopreservation on single umbilical cord blood transplantation outcomes, Biol. Blood Marrow Transplant. 21 (2015) 50-54.

[68] A. Germann, Y.J. Oh, T. Schmidt, U. Schon, H. Zimmermann, H. von Briesen, Temperature fluctuations during deep temperature cryopreservation reduce PBMC recovery, viability and T-cell function, Cryobiology. 67 (2013) 193-200.

[69] B.W. Grout, G.J. Morris, Contaminated liquid nitrogen vapour as a risk factor in pathogen transfer, Theriogenology. 71 (2009) 1079-1082.

[70] C. Hunt, D. Pegg, Improved Temperature Stability in Gas-Phase Nitrogen Refrigerators: Use of a Copper Heat Shunt, Cryobiology. 33 (1996) 544-551.

[71] A. Sputtek, Cryopreservation of red blood cells and platelets, Methods Mol. Biol. 368 (2007) 283-301.

[72] Y. Yuan, Y. Yang, Y. Tian, J. Park, A. Dai, R.M. Roberts, Y. Liu, X. Han, Efficient long-term cryopreservation of pluripotent stem cells at -80 degrees C, Sci. Rep. 6 (2016) 34476.

[73] B. Mishra, S.R. Ragini, I.L. Kashiv, R.K. Ratho, Preservation of continuous cell lines at -85 degrees C: a low-cost alternative for resource limited countries, Indian J. Pathol. Microbiol. 53 (2010) 742-744.

[74] I. Massie, C. Selden, H. Hodgson, B. Fuller, Storage temperatures for cold-chain delivery in cell therapy: a study of alginate-encapsulated liver cell spheroids stored at 80 degrees c or -170 degrees c for up to 1 year, Tissue Eng. Part C. Methods. 19 (2013) 189-195.

[75] W.F. Rall, C. Polge, Effect of warming rate on mouse embryos frozen and thawed in glycerol, J. Reprod. Fertil. 70 (1984) 285-292.

[76] J.O. Karlsson, M. Toner, Long-term storage of tissues by cryopreservation: critical issues, Biomaterials. 17 (1996) 243-256. 
[77] S. Seki, P. Mazur, The dominance of warming rate over cooling rate in the survival of mouse oocytes subjected to a vitrification procedure, Cryobiology. 59 (2009) 75-82.

[78] N. Manuchehrabadi, Z. Gao, J. Zhang, H.L. Ring, Q. Shao, F. Liu, M. McDermott, A. Fok, Y. Rabin, K.G. Brockbank, M. Garwood, C.L. Haynes, J.C. Bischof, Improved tissue cryopreservation using inductive heating of magnetic nanoparticles, Sci. Transl. Med. 9 (2017) 10.1126/scitranslmed.aah4586.

[79] P. Kilbride, S. Lamb, S. Gibbons, J. Bundy, E. Erro, C. Selden, B. Fuller, J. Morris, Cryopreservation and re-culture of a 2.3 litre biomass for use in a bioartificial liver device, PLoS One. 12 (2017) e0183385.

[80] J. Bujan, G. Pascual, R. Lopez, C. Corrales, M. Rodriguez, F. Turegano, J.M. Bellon, Gradual thawing improves the preservation of cryopreserved arteries, Cryobiology. 42 (2001) 256-265.

[81] S. Jitraruch, A. Dhawan, R.D. Hughes, C. Filippi, S.C. Lehec, L. Glover, R.R. Mitry, Cryopreservation of Hepatocyte Microbeads for Clinical Transplantation, Cell Transplant. 26 (2017) 1341-1354.

[82] A. Espona-Noguera, J. Ciriza, A. Canibano-Hernandez, L. Fernandez, I. Ochoa, L. Saenz Del Burgo, J.L. Pedraz, Tunable injectable alginate-based hydrogel for cell therapy in Type 1 Diabetes Mellitus, Int. J. Biol. Macromol. 107 (2018) 1261-1269.

[83] C. Selden, J. Bundy, E. Erro, E. Puschmann, M. Miller, D. Kahn, H. Hodgson, B. Fuller, J. Gonzalez-Molina, A. Le Lay, S. Gibbons, S. Chalmers, S. Modi, A. Thomas, P. Kilbride, A. Isaacs, R. Ginsburg, H. Ilsley, D. Thomson, G. Chinnery, N. Mankahla, L. Loo, C.W. Spearman, A clinical-scale BioArtificial Liver, developed for GMP, improved clinical parameters of liver function in porcine liver failure, Sci. Rep. 7 (2017) 14518-017-15021-4.

[84] A. Gonzalez-Pujana, A. Rementeria, F.J. Blanco, M. Igartua, J.L. Pedraz, E. Santos-Vizcaino, R.M. Hernandez, The role of osmolarity adjusting agents in the regulation of encapsulated cell behavior to provide a safer and more predictable delivery of therapeutics, Drug Deliv. 24 (2017) 1654-1666.

[85] X.M. Luo, H. Lin, W. Wang, M.S. Geaney, L. Law, S. Wynyard, S.B. Shaikh, H. Waldvogel, R.L. Faull, R.B. Elliott, S.J. Skinner, J.E. Lee, P.L. Tan, Recovery of neurological functions in non-human primate model of Parkinson's disease by transplantation of encapsulated neonatal porcine choroid plexus cells, J. Parkinsons Dis. 3 (2013) 275-291.

[86] A.L. Hillberg, K. Kathirgamanathan, J.B. Lam, L.Y. Law, O. Garkavenko, R.B. Elliott, Improving alginate-poly-L-ornithine-alginate capsule biocompatibility through genipin crosslinking, J. Biomed. Mater. Res. B. Appl. Biomater. 101 (2013) 258-268.

[87] R.G. Gomez-Mauricio, A. Acarregui, F.M. Sanchez-Margallo, V. Crisostomo, I. Gallo, R.M. Hernandez, J.L. Pedraz, G. Orive, M.F. Martin-Cancho, A preliminary approach to the repair of myocardial infarction using adipose tissue-derived stem cells 
encapsulated in magnetic resonance-labelled alginate microspheres in a porcine model, Eur. J. Pharm. Biopharm. 84 (2013) 29-39.

[88] C. Selden, C.W. Spearman, D. Kahn, M. Miller, A. Figaji, E. Erro, J. Bundy, I. Massie, S.A. Chalmers, H. Arendse, A. Gautier, P. Sharratt, B. Fuller, H. Hodgson, Evaluation of encapsulated liver cell spheroids in a fluidised-bed bioartificial liver for treatment of ischaemic acute liver failure in pigs in a translational setting, PLoS One. 8 (2013) e82312.

[89] Open-label Investigation of the Safety and Effectiveness of DIABECELL® in Patients With Type I Diabetes Mellitus, 2018 (2018).

[90] R. Calafiore, G. Basta, G. Luca, A. Lemmi, M.P. Montanucci, G. Calabrese, L. Racanicchi, F. Mancuso, P. Brunetti, Microencapsulated pancreatic islet allografts into nonimmunosuppressed patients with type 1 diabetes: first two cases, Diabetes Care. 29 (2006) 137-138.

[91] R. Calafiore, G. Basta, G. Luca, A. Lemmi, L. Racanicchi, F. Mancuso, M.P. Montanucci, P. Brunetti, Standard technical procedures for microencapsulation of human islets for graft into nonimmunosuppressed patients with type 1 diabetes mellitus, Transplant. Proc. 38 (2006) 1156-1157.

[92] Investigation of the Safety and Efficacy of NTCELL® [Immunoprotected (Alginate-Encapsulated) Porcine Choroid Plexus Cells for Xenotransplantation] in Patients With Parkinson's Disease, 2018 (2018).

[93] K. Inaba, D. Zhou, B. Yang, I. Vacek, A.M. Sun, Normalization of diabetes by xenotransplantation of cryopreserved microencapsulated pancreatic islets. Application of a new strategy in islet banking, Transplantation. 61 (1996) 175-179.

[94] Y. Matsumoto, Y. Morinaga, M. Ujihira, K. Oka, K. Tanishita, Improvement in the Viability of Cryopreserved Cells By Microencapsulation, 44 (2001) 937-945.

[95] B.G. Li, T.C. Hua, H.D. Zhang, Y.F. Wang, G.X. Wang, Cryopreservation and xenotransplantation studies of microencapsulated rat pancreatic islets, Cryo Letters. 23 (2002) 47-54.

[96] R. Malpique, L.M. Osorio, D.S. Ferreira, F. Ehrhart, C. Brito, H. Zimmermann, P.M. Alves, Alginate encapsulation as a novel strategy for the cryopreservation of neurospheres, Tissue Eng. Part C. Methods. 16 (2010) 965-977.

[97] R. Malpique, F. Ehrhart, A. Katsen-Globa, H. Zimmermann, P.M. Alves, Cryopreservation of adherent cells: strategies to improve cell viability and function after thawing, Tissue Eng. Part C. Methods. 15 (2009) 373-386.

[98] C. Guyomard, L. Rialland, B. Fremond, C. Chesne, A. Guillouzo, Influence of alginate gel entrapment and cryopreservation on survival and xenobiotic metabolism capacity of rat hepatocytes, Toxicol. Appl. Pharmacol. 141 (1996) 349-356. 
[99] L. Rialland, C. Guyomard, M. Scotte, C. Chesne, A. Guillouzo, Viability and drug metabolism capacity of alginate-entrapped hepatocytes after cryopreservation, Cell Biol. Toxicol. 16 (2000) 105-116.

[100] E.E. Benson, K. Harding, M. Ryan, A. Petrenko, Y. Petrenko, B. Fuller, Alginate Encapsulation to enhance Biopreservation scope and succces: a multidisciplinary review of current ideas and applications in cryopreservation and non-freezing storage, CryoLetters. 39 (2018) 14-38.

[101] N. Murase, T. Inoue, M. Ruike, Equilibrium and nonequilibrium freezing of water in cross-linked dextran gels, 18 (1997) 157.

[102] M. Toner, E.G. Cravalho, M. Karel, Cellular response of mouse oocytes to freezing stress: prediction of intracellular ice formation, J. Biomech. Eng. 115 (1993) 169-174.

[103] P. Mazur, The role of cell membranes in the freezing of yeast and other single cells, Ann. N. Y. Acad. Sci. 125 (1965) 658-676.

[104] H.G. Koebe, J.C. Dunn, M. Toner, L.M. Sterling, A. Hubel, E.G. Cravalho, M.L. Yarmush, R.G. Tompkins, A new approach to the cryopreservation of hepatocytes in a sandwich culture configuration, Cryobiology. 27 (1990) 576-584.

[105] B. Ludwig, A. Reichel, A. Steffen, B. Zimerman, A.V. Schally, N.L. Block, C.K. Colton, S. Ludwig, S. Kersting, E. Bonifacio, M. Solimena, Z. Gendler, A. Rotem, U. Barkai, S.R. Bornstein, Transplantation of human islets without immunosuppression, Proc. Natl. Acad. Sci. U. S. A. 110 (2013) 19054-19058.

[106] H. Gurruchaga, L. Saenz del Burgo, J. Ciriza, G. Orive, R.M. Hernandez, J.L. Pedraz, Advances in cell encapsulation technology and its application in drug delivery, Expert Opin. Drug Deliv. 12 (2015) 1251-1267.

[107] G. Basta, P. Montanucci, G. Luca, C. Boselli, G. Noya, B. Barbaro, M. Qi, K.P. Kinzer, J. Oberholzer, R. Calafiore, Long-term metabolic and immunological follow-up of nonimmunosuppressed patients with type 1 diabetes treated with microencapsulated islet allografts: four cases, Diabetes Care. 34 (2011) 2406-2409.

[108] D. Zhou, I. Vacek, A.M. Sun, Cryopreservation of microencapsulated porcine pancreatic islets: in vitro and in vivo studies, Transplantation. 64 (1997) 1112-1116.

[109] S. Schneider, H.H. Klein, Long-term graft function of cryostored alginate encapsulated rat islets, Eur. J. Med. Res. 16 (2011) 396-400.

[110] H.F. Ahmad, N.E. Simpson, A.N. Lawson, A. Sambanis, Cryopreservation effects on intermediary metabolism in a pancreatic substitute: a (13)C nuclear magnetic resonance study, Tissue Eng. Part A. 18 (2012) 2323-2331.

[111] A. Gebler, O. Zabel, B. Seliger, The immunomodulatory capacity of mesenchymal stem cells, Trends Mol. Med. 18 (2012) 128-134. 
[112] M. Shi, Z.W. Liu, F.S. Wang, Immunomodulatory properties and therapeutic application of mesenchymal stem cells, Clin. Exp. Immunol. 164 (2011) 1-8.

[113] W.C. Mak, B. Magne, K.Y. Cheung, D. Atanasova, M. Griffith, Thermorheological responsive microcapsules for time-dependent controlled release of human mesenchymal stromal cells, Biomater. Sci. 5 (2017) 2241-2250.

[114] A. Garate, J. Ciriza, J.G. Casado, R. Blazquez, J.L. Pedraz, G. Orive, R.M. Hernandez, Assessment of the Behavior of Mesenchymal Stem Cells Immobilized in Biomimetic Alginate Microcapsules, Mol. Pharm. 12 (2015) 3953-3962.

[115] L. Saenz Del Burgo, J. Ciriza, A. Acarregui, H. Gurruchaga, F.J. Blanco, G. Orive, R.M. Hernandez, J.L. Pedraz, Hybrid Alginate-Protein-Coated Graphene Oxide Microcapsules Enhance the Functionality of Erythropoietin Secreting C2C12 Myoblasts, Mol. Pharm. 14 (2017) 885-898.

[116] O. Gryshkov, D. Pogozhykh, N. Hofmann, O. Pogozhykh, T. Mueller, B. Glasmacher, Encapsulating non-human primate multipotent stromal cells in alginate via high voltage for cell-based therapies and cryopreservation, PLoS One. 9 (2014) e107911.

[117] O. Gryshkov, N. Hofmann, L. Lauterboeck, D. Pogozhykh, T. Mueller, B. Glasmacher, Multipotent stromal cells derived from common marmoset Callithrix jacchus within alginate 3D environment: Effect of cryopreservation procedures, Cryobiology. 71 (2015) 103-111.

[118] A. Sgroi, G. Mai, P. Morel, R.M. Baertschiger, C. Gonelle-Gispert, V. SerreBeinier, L.H. Buhler, Transplantation of encapsulated hepatocytes during acute liver failure improves survival without stimulating native liver regeneration, Cell Transplant. 20 (2011) 1791-1803.

[119] S. Harm, K. Stroble, J. Hartmann, D. Falkenhagen, Alginate-encapsulated human hepatoma C3A cells for use in a bioartificial liver device - the hybrid-MDS, Int. J. Artif. Organs. 32 (2009) 769-778.

[120] V. Dixit, R. Darvasi, M. Arthur, K. Lewin, G. Gitnick, Cryopreserved microencapsulated hepatocytes--transplantation studies in Gunn rats, Transplantation. 55 (1993) 616-622.

[121] L. Canaple, N. Nurdin, N. Angelova, D. Saugy, D. Hunkeler, B. Desvergne, Maintenance of primary murine hepatocyte functions in multicomponent polymer capsules--in vitro cryopreservation studies, J. Hepatol. 34 (2001) 11-18.

[122] G. Mai, T.H. Nguyen, P. Morel, J. Mei, A. Andres, D. Bosco, R. Baertschiger, C. Toso, T. Berney, P. Majno, G. Mentha, D. Trono, L.H. Buhler, Treatment of fulminant liver failure by transplantation of microencapsulated primary or immortalized xenogeneic hepatocytes, Xenotransplantation. 12 (2005) 457-464.

[123] J. Mei, A. Sgroi, G. Mai, R. Baertschiger, C. Gonelle-Gispert, V. Serre-Beinier, P. Morel, L.H. Buhler, Improved survival of fulminant liver failure by transplantation of 
microencapsulated cryopreserved porcine hepatocytes in mice, Cell Transplant. 18 (2009) 101-110.

[124] H. Hang, X. Shi, G. Gu, Y. Wu, J. Gu, Y. Ding, In vitro analysis of cryopreserved alginate-poly-L-lysine-alginate-microencapsulated human hepatocytes, Liver Int. 30 (2010) 611-622.

[125] E. Erro, J. Bundy, I. Massie, S.A. Chalmers, A. Gautier, S. Gerontas, M. Hoare, P. Sharratt, S. Choudhury, M. Lubowiecki, I. Llewellyn, C. Legallais, B. Fuller, H. Hodgson, C. Selden, Bioengineering the liver: scale-up and cool chain delivery of the liver cell biomass for clinical targeting in a bioartificial liver support system, Biores Open Access. 2 (2013) 1-11.

[126] I. Massie, C. Selden, J. Morris, H. Hodgson, B. Fuller, Cryopreservation of encapsulated liver spheroids using a cryogen-free cooler: high functional recovery using a multi-step cooling profile, Cryo Letters. 32 (2011) 158-165.

[127] P. Kilbride, S. Lamb, S. Milne, S. Gibbons, E. Erro, J. Bundy, C. Selden, B. Fuller, J. Morris, Spatial considerations during cryopreservation of a large volume sample, Cryobiology. 73 (2016) 47-54.

[128] A. Murua, G. Orive, R.M. Hernandez, J.L. Pedraz, Cryopreservation based on freezing protocols for the long-term storage of microencapsulated myoblasts, Biomaterials. 30 (2009) 3495-3501.

[129] H.F. Ahmad, A. Sambanis, Cryopreservation effects on recombinant myoblasts encapsulated in adhesive alginate hydrogels, Acta Biomater. 9 (2013) 6814-6822.

[130] Z. Shu, H. Chen, X. Zhou, D. Gao, Assessment of Cryoprotectant Concentration by Electrical Conductivity Measurement and Its Applications in Cryopreservation, in: Anonymous Electrical Resistivity and Conductivity, Intech, 2017, pp. 97-114.

[131] B. Calmels, P. Houze, J.C. Hengesse, T. Ducrot, C. Malenfant, C. Chabannon, Preclinical evaluation of an automated closed fluid management device: Cytomate, for washing out DMSO from hematopoietic stem cell grafts after thawing, Bone Marrow Transplant. 31 (2003) 823-828.

[132] L. Rodriguez, C. Azqueta, S. Azzalin, J. Garcia, S. Querol, Washing of cord blood grafts after thawing: high cell recovery using an automated and closed system, Vox Sang. 87 (2004) 165-172.

[133] C.G. Perotti, C. Del Fante, G. Viarengo, P. Papa, L. Rocchi, P. Bergamaschi, L. Bellotti, A. Marchesi, L. Salvaneschi, A new automated cell washer device for thawed cord blood units, Transfusion. 44 (2004) 900-906.

[134] A. Bissoyi, B. Nayak, K. Pramanik, S.K. Sarangi, Targeting cryopreservationinduced cell death: a review, Biopreserv Biobank. 12 (2014) 23-34. 
[135] A. Bissoyi, K. Pramanik, Role of the apoptosis pathway in cryopreservationinduced cell death in mesenchymal stem cells derived from umbilical cord blood, Biopreserv Biobank. 12 (2014) 246-254.

[136] E. Santos, J.L. Pedraz, R.M. Hernandez, G. Orive, Therapeutic cell encapsulation: ten steps towards clinical translation, J. Control. Release. 170 (2013) 1-14.

[137] A. Holbro, H. Baldomero, F. Lanza, C. Chabannon, J.A. Snowden, A. Buser, L. Infanti, N. Worel, A. Sureda, M. Badoglio, J. Passweg, C. Bonini, Cellular Therapy \& Immunobiology Working Party of the European Society for Blood \& Marrow Transplantation (EBMT) and the Joint Accreditation Committee International Society for Cellular Therapy \& EBMT (JACIE), Handling, processing and disposal of stem cell products in Europe: A survey by the cellular therapy and immunobiology working party of the European Society for Blood and Marrow Transplantation, Cytotherapy. 20 (2018) 453-460. 